\title{
Diagnóstico del deterioro de la piedra en el patrimonio construido. Datos y perspectivas
}

\section{Diagnosing stone decay in built heritage. Facts and perspectives}

\author{
F. Veniale(*,**), M. Setti ${ }^{(* *)}$ y S. Lodola(***)
}

Recepción/Received: 24-V-07

Aceptación/Accepted: 28-IX-07

Publicado online/Online publishing: 6-II-07

\section{RESUMEN}

La piedra y otros materiales utilizados para construir edificios históricos, estatuas conmemorativas, lápidas, etc. sufren la acción de los agentes atmosféricos y contaminantes $y$, por tanto, a una degradación progresiva. En dicha degradación, ya sea física, química o biológica, intervienen las fases minerales de la piedra y sus correspondientes interrelaciones (estructura y textura).

Un análisis de los procedimientos analíticos aplicados en la investigación científica sobre los daños en la piedra ha puesto de manifiesto la necesidad de herramientas y pruebas adecuadas (cada una con un objetivo concreto, según el daño existente) para identificar los procesos de degradación y aplicar la "terapia" adecuada; es decir, una protección provisional o definitiva (limpieza, protección, refuerzo, reparación o sustitución).

Se comentan varios casos prácticos relacionados con conocidos elementos del patrimonio construido italiano en el contexto del empleo de metodologías integradas para la investigación de la degradación en distintos tipos de piedra.

Palabras clave: patrimonio costruido, piedra, mortero, deterioro, diagnóstico.

\section{SUMMARY}

Stone and other materials used for the construction of historic buildings, memorial statues, gravestones and similar are exposed to weathering and polluting agents and, therefore, progressive decay. Such deterioration, whether physical, chemical or biological, involves mineral phases and their interrelationships (structure and texture).

A review of the analytical procedures applied in scientific research on stone damage has revealed the need for appropriate tools and tests (each with a specific scope, depending on the extant damage) to identify decay processes and apply the correct "therapy", i.e. temporary and/or permanent protection (cleaning, protection, reinforcement, repair and/or replacement).

A number of case histories of famous components of the Italian built heritage are discussed in the context of the use of integrated methodologies for researching decay in different kinds of stone.

Keywords: built heritage, stone, mortar, decay, diagnosis.

(*) Comité internacional para la Salvaguardia de la Torre de Pisa.

(**) Universidad de Pavía (Italia).

(***) Proyecto de Restauración de la Torre de Pisa. 


\section{INTRODUCCIÓN}

Los edificios históricos, las murallas de una ciudad, las torres y otros elementos similares están construidos principalmente con piedra y ladrillo, junto con otros materiales cerámicos (tejas, adornos de terracota...). Otros materiales de construcción importantes son el mortero que se utiliza para recibir los elementos de piedra, de ladrillo o cerámicos, los revocos y el yeso (empleados también para la reparación de edificios, ya sea mezclados con cemento o no), y metales en elementos como balcones, escaleras, balaustradas, ventanas y ornamentos, así como para reforzar las partes debilitadas de las estructuras de los edificios.

La "calidad" de la piedra es fundamental para el comportamiento estático y dinámico de las unidades constructivas. La piedra ha sufrido y sigue sufriendo distintos tipos de "patologías" (daños físicos, químicos o biológicos) y procesos de degradación más o menos intensos.

La degradación física está relacionada principalmente con causas naturales, como las fluctuaciones de temperatura, el viento y la lluvia.

Los procesos de alteración química se deben principalmente a agentes atmosféricos (naturales o antropogénicos) que dan lugar a la corrosión, disolución y exfoliación de los materiales que se encuentran a la intemperie, así como la precipitación y la cristalización de costras y pátinas.

El deterioro biogénico tiene su origen en la colonización y penetración en la piedra de microorganismos alrededor de los granos y en microfisuras.

Un mayor conocimiento de los procesos que participan en el deterioro de la piedra exige análisis mineralógicos, petrográficos y de estructura y textura detallados, así como pruebas petrofísicas tanto en zonas intactas como dañadas; es fundamental registrar de forma precisa las consecuencias de la degradación de cara a las intervenciones de restauración.

Los enfoques modernos para la exploración de la degradación de la piedra hacen uso de varios equipos y metodologías tradicionales y avanzadas, así como procedimientos innovadores, de ciencias de la tierra y de los materiales que son necesarios para seleccionar el protocolo de restauración más adecuado (limpieza, protección, refuerzo, reparación o sustitución).

A continuación se hablará sobre casos prácticos de conocidos lugares históricos italianos (la Torre Inclinada de Pisa, la Catedral de San Pedro de Roma, la Basílica de San Miguel y la Cartuja de Pavía) y se ofrecerán datos inédi-

\section{INTRODUCTION}

Historic buildings, city walls, towers and similar are made primarily of stone and/or brick, along with other claybased or ceramic materials (roof tiles, terracotta ornaments and so forth). Other important building materials include the mortar used to join stone, brick and ceramic elements, rendering products and plaster (also used in building repair, mixed with cement or otherwise), and metals on elements such as balconies, staircases, balustrades, windows and ornaments and to reinforce weakened parts of building structures.

Stone "quality" is essential to the static and dynamic behaviour of building units. Stone has undergone and continues to undergo various kinds of "pathologies" (physical, chemical or biological damage) and more or less intense decay processes.

Physical degradation is related primarily to natural causes: temperature fluctuations, wind and wind-driven rain among them.

Chemical alteration processes are mainly due to atmospheric agents (natural and/or anthropogenic) that cause corrosion, dissolution and detachment of exposed materials, as well as the precipitation and crystallization of crusts and patinas.

The origin of biogenic deterioration lies in stone colonization and penetration by micro-organisms around grains and in micro-fissures.

A deeper understanding of the processes involved in stone deterioration calls for detailed mineralogical, petrographic and structural-textural analyses, together with petrophysical tests of both unaltered and damaged areas; accurate records on decay by-products are of vital importance to restoration interventions.

Modern approaches to the exploration of stone decay deploy a number of traditional and advanced geo-and material-sciences tools and methodologies, as well as innovative procedures, needed to select the most suitable restoration protocol (cleaning, protection, reinforcement, repair and/or replacement).

Case histories of famous Italian heritage sites (leaning Tower of Pisa, St. Peter's Cathedral in Rome, St. Michael's Basilica, the Carthusian Monastery at Pavia) are reported hereunder, along with unpublished data. These studies 
tos. Estos estudios muestran cómo los procedimientos en los que se integran metodologías analíticas tradicionales y avanzadas pueden proporcionar un conocimiento detallado de la composición y de las propiedades petrofísicas de la piedra, así como de los procesos que la dañan, con vistas a seleccionar y poner en práctica las medidas de conservación y restauración adecuadas.

\section{PROCEDIMIENTOS DE INVESTIGACIÓN}

Los estudios históricos y los archivos pueden proporcionar información decisiva para datar la construcción y conocer los materiales usados, los daños reparados, las prácticas y las fases de construcción.

La representación preliminar de la distribución de litotipos en los distintos elementos arquitectónicos y los análisis de "patologías" de los materiales son fundamentales y pueden resultar especialmente útiles cuando se complementan con documentación fotográfica y formulaciones fotogramétricas.

La situación que puede observarse hoy día es el resultado de siglos de acción agresiva por parte de los agentes ambientales. Por otro lado, el deterioro superficial en forma de costras o pátinas puede proteger la piedra subyacente, contribuyendo a la compactación de la piedra e impidiendo una degradación apreciable del sustrato. Son necesarios sistemas de información adecuados capaces de representar el estado de la piedra para documentar y procesar los datos recogidos en ese sentido, que se han convertido en indispensables para elegir y planificar las medidas de conservación.

El dilema al que se enfrentan los investigadores que estudian los materiales de los edificios y monumentos históricos es si deben emplear ensayos destructivos o no destructivos. Aunque ese problema resulta irrelevante para el estudio de muestras de cantera, cuando la piedra es un elemento de construcción o escultórico se recomienda la utilización de ensayos no destructivos. Aun así, pueden obtenerse muestras representativas mediante microtestigos y cortes finos.

Además de los equipos y procedimientos tradicionales para determinar la composición (microscopía petrográfica, análisis químicos, difracción por rayos $\mathrm{X}$ ), suelen realizarse otras pruebas para determinar las propiedades mecánicas. Por otra parte, también se han puesto en práctica técnicas avanzadas, cada una en un ámbito concreto y aplicada en función de la naturaleza y estado del material y de la necesidad de intervención.

Las lagunas en el conocimiento actual sobre los mecanismos de deterioro pueden afectar a la hora de evaluar la show how procedures integrating routine and advanced analytical methodologies can provide detailed knowledge of stone composition, petrophysical properties and damage processes with a view to selecting and implementing appropriate preservation and restoration measures.

\section{RESEARCH PROCEDURES}

Historical studies and archives can provide information instrumental to dating structures, materials used and damage repaired in the past as well as on building practices and stages.

The preliminary mapping of lithotype distribution in the various architectural elements and surveys of material "pathology" are essential, and may be especially useful when supplemented with photographic documentation and photogrammetric formulations.

The situation observed today is the result of centuries of aggressive action by environmental agents; at the same time, superficial decay in the form of crusts or patinas may protect the underlying stone by contributing to stone compactness and preventing appreciable degradation of the substrate. Suitable information systems able to represent the condition of stone materials are needed to document and process the data collected in this regard and have become indispensable for choosing and planning preservation measures.

The dilemma facing researchers studying materials in historic buildings and monuments is whether to deploy destructive or non-destructive tests. While such an issue is irrelevant to the study of quarry samples, when stone is a building component or a sculptural element, non-destructive tests are recommended. Even so, representative samples can be obtained with micro-cores and thin cuts.

In addition to routine tools and procedures for determining composition (petrographic microscopy, chemical analysis, X-ray diffraction), other tests are usually conducted to ascertain mechanical properties. Moreover, advanced techniques have also been implemented, each in a scope specific to the nature and condition of the materials and the need for intervention.

Gaps in the present state of knowledge of deterioration mechanisms may affect the assessment of the relative 
importancia relativa de los distintos procesos y sus interrelaciones. La combinación de la observación in situ, los análisis de laboratorio y la modelación y simulación permite una evaluación fiable, desde el punto de vista científico, de los parámetros necesarios para diagnosticar el deterioro de la piedra, ya sea éste visible o no.

Con estas vías de investigación y el seguimiento realizado con el tiempo, puede representarse y preverse la evolución futura.

\section{METODOLOGÍA INTEGRAL DE INVESTIGA- CIÓN: APLICACIONES Y PERSPECTIVAS}

Las vías adecuadas para el estudio del estado de los materiales en edificios históricos y la planificación de su reparación y mantenimiento deberían incluir: "anatomía, diagnóstico y terapia": (1-9) y las referencias citadas en ellas.

Un diagnóstico coherente de las formas de alteración y de su velocidad de avance es fundamental para evaluar la necesidad y la urgencia, así como para diseñar, las medidas de protección y mantenimiento adecuadas. El aspecto y la morfología de los productos del deterioro han sido objeto de definición y clasificación (10), existiendo en Italia un léxico normalizado (11).

Se ha desarrollado para la ocasión un sistema informatizado (12) basado en la inspección visual y los estudios fotogramétricos para obtener mapas de distribución de los materiales de construcción de la Torre Inclinada de Pisa, su degradación (Figura 1a) y sus variaciones con el tiempo (Figura 1b). Un segundo objetivo de este software es documentar y realizar un seguimiento del proyecto de restauración que está realizando actualmente el Istituto Centrale per il Restauro (13).

El sistema, que ha recibido el nombre de "Leaning Tower Akira-GIS Server", almacena, muestra y gestiona las enormes cantidades de datos recogidos de documentos y archivos históricos, análisis de la distribución de los litotipos y de las formas de alteración, y ensayos de campo y de laboratorio. Su base gráfica y geométrica incluye funciones estadísticas con las que es posible averiguar la frecuencia y distribución de una serie de parámetros, lo que supuso un valioso apoyo para elaborar el borrador del Proyecto de Restauración de la torre y resultará asimismo útil para supervisar el mantenimiento posterior.

Puede obtenerse más información sobre el Comité Internacional para la Salvaguardia de la Torre de Pisa y sobre las investigaciones en marcha, así como informes internos y proyectos, en el sitio web www.opapisa.it/piazza; véase también (14). importance of different processes and their interrelationships. The combination of "in situ" observation, laboratory analysis and modelling simulation provides for a scientifically reliable evaluation of the parameters needed to diagnose stone deterioration on visible and non-visible scales.

With such research pathways and monitoring over time, future evolution can be represented and predicted.

\section{COMPREHENSIVE RESEARCH METHODO- LOGY: APPLICATIONS AND PERSPECTIVES}

Suitable pathways for studying the condition of materials in historic buildings and planning their repair and maintenance should include: "anatomy, diagnosis and therapy": (1-9) and references therein.

A meaningful diagnosis of the forms of alteration and their rate of progression is imperative to evaluating the need and urgency of and designing appropriate protective and maintenance measures. The appearance and morphology of decay by-products have been defined and classified (10); standardized terminology is in place in Italy (11).

An "ad hoc" computerized system (12) based on visual inspection and photogrammetric surveys has been developed to map the building materials in the leaning Tower of Pisa and their degradation (Figure 1,a) and variations over time (Figure 1,b). A second aim of this software is to document and monitor the restoration project currently underway under the auspices of the Italian Istituto Centrale per il Restauro (13).

Christened as the "Leaning Tower Akira-GIS Server", the system stores, displays and manages the vast amounts of data collected from historic documentation and archives, analyses of lithotype distribution and forms of alteration, and field and laboratory tests. Its graphic and geometric base features and statistical functionalities with which the frequency and distribution of a number of parameters were readily found, are providing valuable support for drafting the Restoration Project for the tower; it will also be useful for supervising subsequent maintenance.

Further information on the International Committee for Safeguarding the Pisa Tower and the ongoing research, along with internal reports and projects, are available on the website: www.opapisa.it/piazza; see also (14). 
Se han identificado quince litotipos, cada uno con varios colores y texturas, como materiales originales o de sustitución en la torre. Además, se han asociado sus propiedades mecánicas con las distintas consecuencias de la degradación: costras negras, eflorescencias, pátinas, "abrasamiento", termoclastismo por isolación, exfoliación y abrasión.

Por ejemplo, gracias al sistema pudo hacerse un esquema de las dimensiones y la orientación espacial de las vetas en las columnas de mármol de las logias de la torre (15) (Figura 2). Estos datos son muy útiles para evaluar el comportamiento mecánico de las columnas solicitadas por las fuerzas de compresión, la acción del viento, los cambios de temperatura o los movimientos sísmicos, por poner algunos ejemplos.
Fifteen lithotypes, each with a number of colours and textures, have been identified as original and replacement materials in the tower; in addition, their mechanical properties have been associated with the various decay byproducts: black crust, efflorescence, patinas, insulation damage, "scorching" damage, detachment and abrasion.

For instance, the dimensions and spatial orientation of the veins in the marble columns of the tower "loggias" could be diagrammed with the system (15) (Figure 2); these data are very useful to evaluating the mechanical behaviour of the columns under stress caused by compression, wind action, temperature fluctuations or seismic events, to name a few.

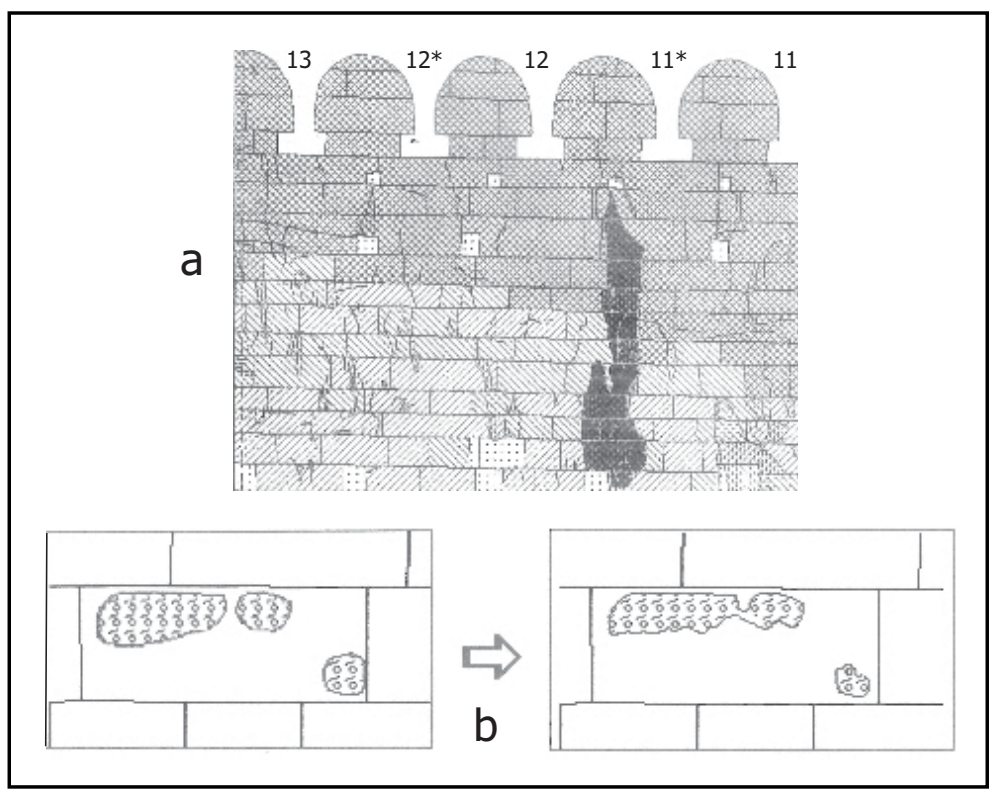

Figura 1. (a) Mapa de distribución de litotipos, consecuencias del deterioro y fisuras. Muro exterior de la Torre de Pisa.

(b) Visualización de la evolución a lo largo del tiempo de los productos de la degradación (12).

Figure 1. (a) Mapping of lithotypes, decay by-products and fissures, outside wall of Pisa tower.

(b) Visualization of variations over time at the site of a decay by-product (12)

Se ha desarrollado un innovador sistema para obtener mapas de riesgo de la estructura de la torre (16). El riesgo localizado se identifica basándose en la intensidad de las tensiones a las que se somete la estructura (determinadas en términos de compresión vertical, la velocidad del sonido y las anomalías detectadas por radar) junto con el grado de deterioro de la piedra. A partir del gráfico de la figura 3 puede establecerse un "índice de riesgo" localizado de 4 niveles que permite identificar las áreas en las que es necesario el refuerzo, evitando de este modo las intervenciones ineficaces o perjudiciales.

La velocidad de deterioro puede estar influida por el modo en que se trabajó la superficie de la piedra (pico, gradina,
An innovative system for mapping risk in the tower structure has been developed (16). Local risk is identified on the grounds of the intensity of the stress on the structure (determined in terms of vertical compression, sonic velocity and radar anomalies) in conjunction with the degree of stone deterioration. Further to the graph in Figure 3, a four-step local "risk index" can be established to detect the areas where strengthening is needed and preclude useless or detrimental interventions.

The way the stone surface was worked (with a point or a toothed, flat or round chisel, toothed axe, sculptor's pick, 


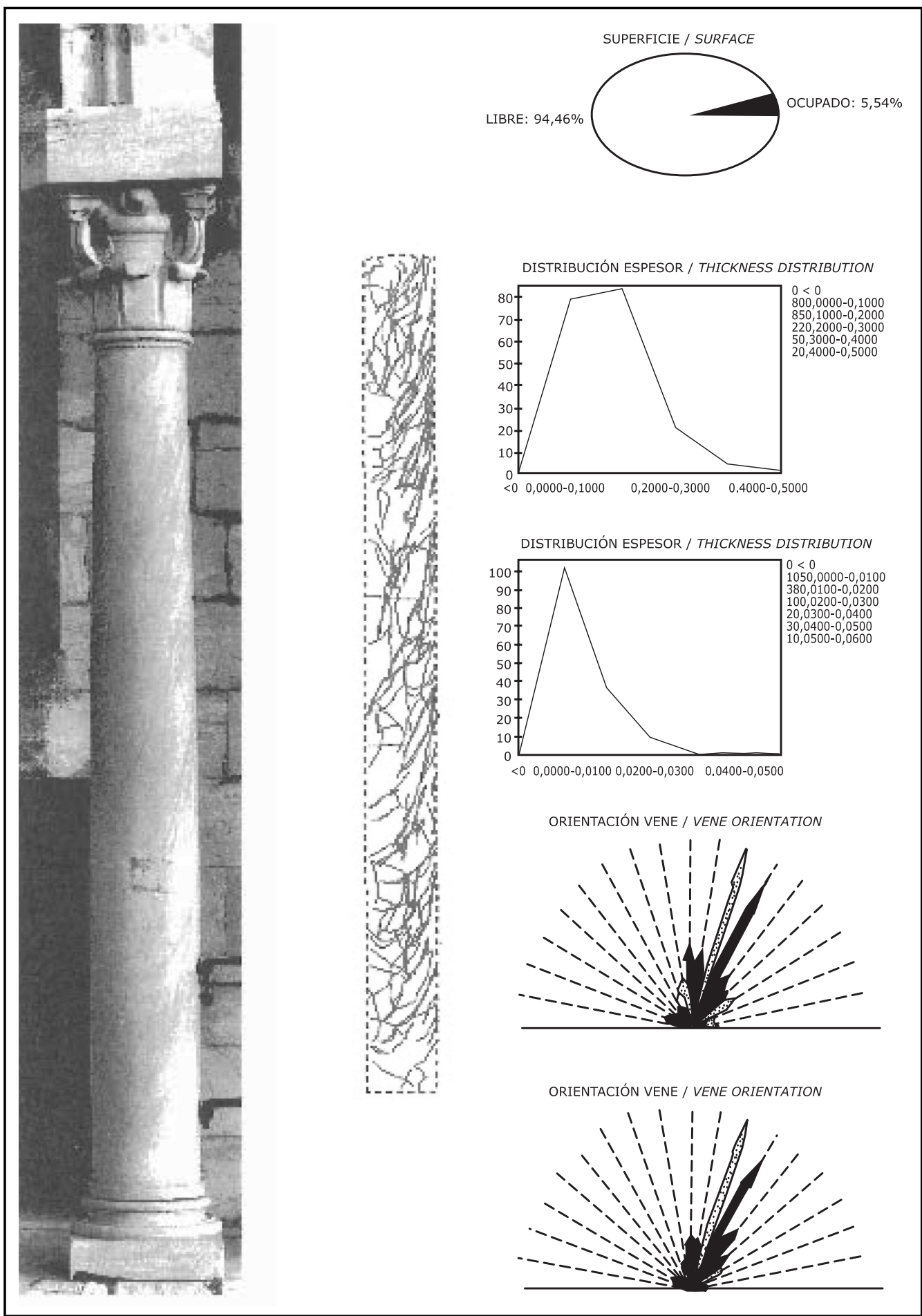

Figura 2. Diagrama representando la orientación de las vetas en una columna de las logias de la Torre de Pisa (15). Figure 2. Diagram representing vein orientation in a column in the Pisa tower loggia (15).

escoplo, cincel redondo, diente de perro, hacha dentada, abujarda, fresa o escofina), normalmente para dar el acabado o con fines estéticos. Se han identificado varios procedimientos de trabajo (17) en la superficie de la piedra de fábrica ("conci") de la estructura cilíndrica de la Torre de Pisa (Figura 4). bush hammer, drill or rasp), usually for finishing and/or aesthetic purposes, can impact the decay rate. Several working procedures have been identified (17) on the surface of the dimension stone ("conci") in the cylindrical structure of the Pisa tower (Figure 4). 
La metodología utilizada por (18) permite procesar imágenes "falsas" en color en combinación con pruebas de ultrasonidos. Al combinar ambos procedimientos pueden verse la configuración espacial y el alcance en profundidad del daño.
The methodology used (18) makes it possible to process "false" colour images associated with ultrasonic testing; when combined, the two procedures show the spatial configuration and depth of damage.

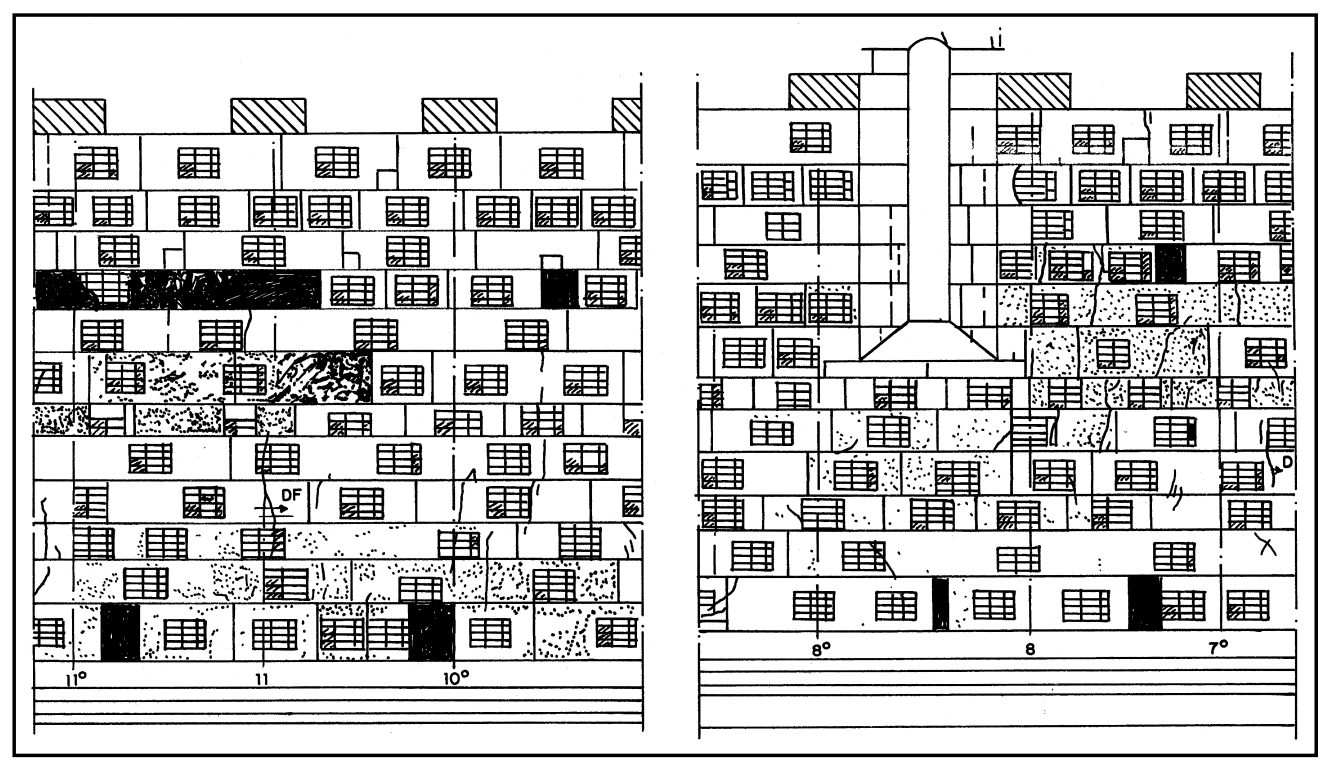

Figura 3. Mapa integrado del "índice de riesgo" de una parte del muro exterior de la Torre de Pisa (16). Figura 3. "Integrated" mapping of the "risk index" in a section of outside wall on Pisa tower (16).

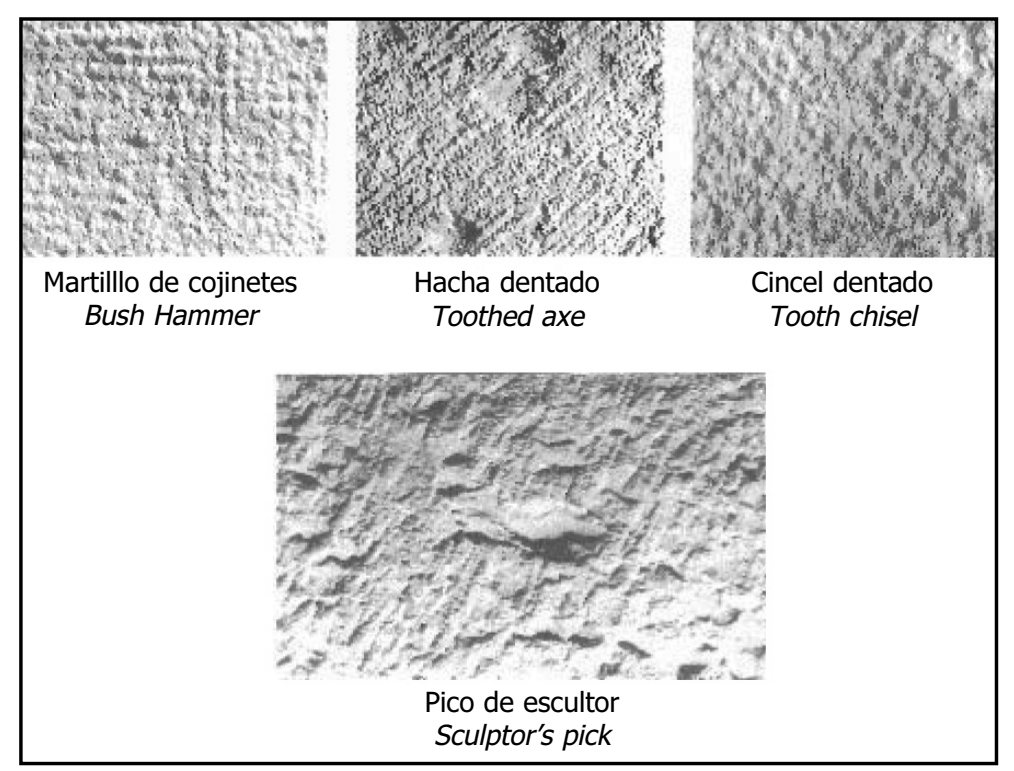

Figura 4. Ejemplos de distintos modos de trabajar la piedra de la Torre de Pisa (13).

Figura 4. Examples of stoneworking in Pisa tower (13)

Se aplicó un sofisticado procedimiento en el que se empleó un dispositivo óptico microtopográfico para cuantificar la velocidad de erosión de los bajorrelieves esculpidos en los bloques de arenisca (petrofacies de grauvaca)
A sophisticated procedure using a micro-topographic optical device (19) was applied to quantify the erosion rate of bas-relief ornaments sculpted in the sandstone (greywacke petrofacies) blocks on the facade of 
de la fachada de la Basílica de San Miguel de Pavía, uno de los ejemplos más destacados de arquitectura románica (siglo XII) del norte de Italia.

El estudio (Figura 5) reveló que el deterioro producido entre 1985 y 1989 fue significativamente más intenso (>20 \%) que el producido en el periodo 1965-1985, debido probablemente a la mayor contaminación atmosférica.

En 1999 se realizó un estudio de estereofotogrametria laser de la misma piedra arenisca (20). La precisión de
St. Michael's Basilica at Pavia, one of the most outstanding examples of Romanesque architecture (XII century) in northern Italy.

The survey (Figure 5) revealed that the deterioration occurring between 1985 and 1989 was significantly more intense (>20\%) than in the period from 1965 to 1985 , probably due to greater air pollution.

A laser stereo-photogrammetric survey of the same sandstone was performed in 1999 (20). The precision of

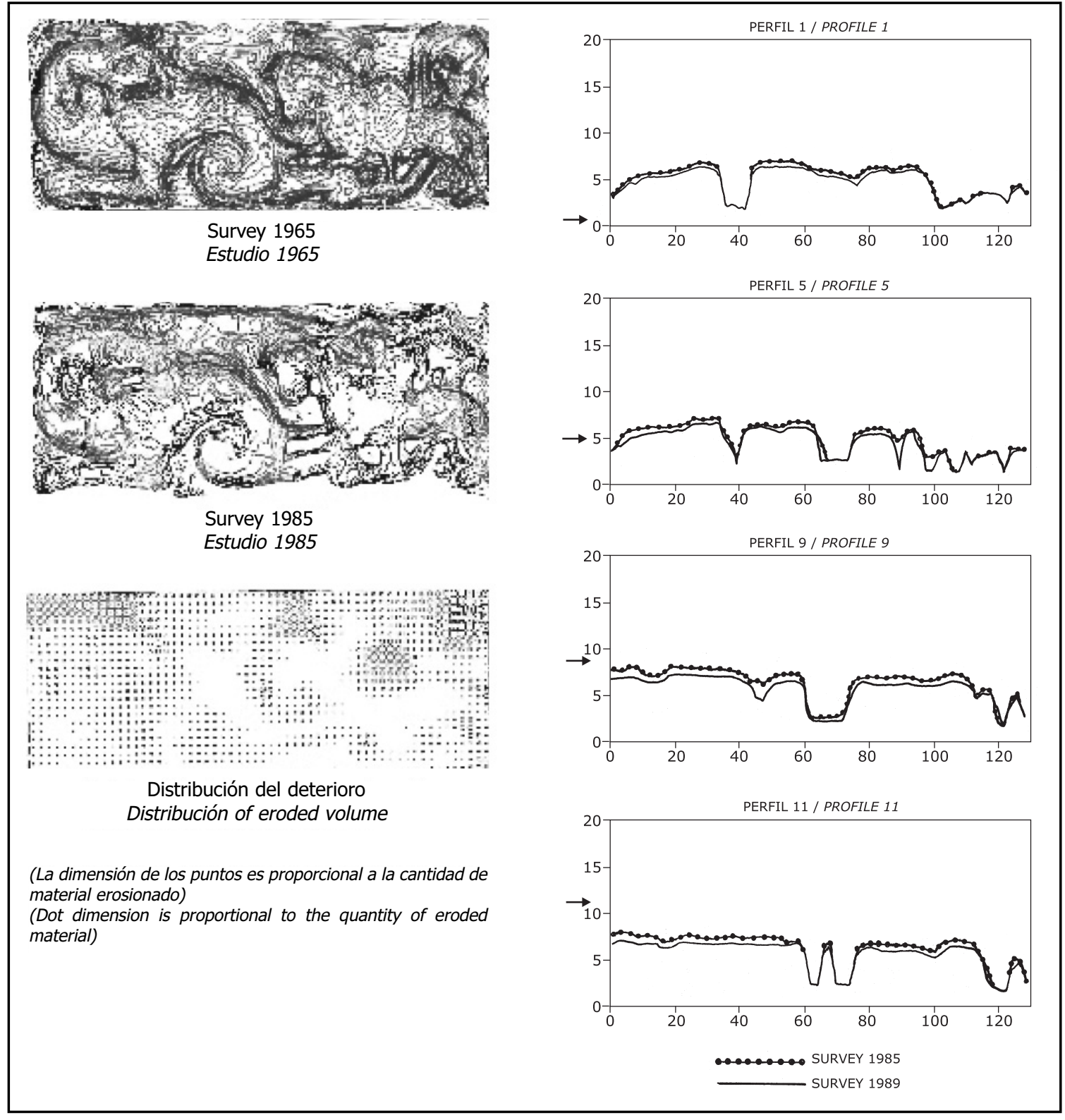

Figura 5. Análisis microtopográficos de un bajorrelieve de arenisca realizados en 1965, 1985 y en 1989; fachada románica de la Basílica de San Miguel de Pavía, en el norte de Italia (19).

Figure 5. Micro-topographic surveys of a "bas-relief" sandstone sculpture conducted in 1965, 1985 and 1989; from the Romanesque façade of St. Michael's Basilica at Pavia, northern Italy (19). 
estas mediciones reveló los efectos negativos de un tratamiento de silicato de $Z n-M g-F$ aplicado en la década de los sesenta y aplicado nuevamente hace poco pese a las recomendaciones en contrario. De hecho, ese tratamiento endureció sólo la superficie de la piedra (2-3 mm de profundidad), que, al ser muy frágil, comenzó pronto a exfoliarse de forma espectacular. Este mecanismo de degradación se detectó en los mapas de distribución de los elementos trazados mediante microscopía electrónica de barrido (MEB) en combinación con espectroscopía de energías dispersivas (EDS) (Figura 6). Los resultados demostraron que la difusión de sílice producía la disolución de la matriz de carbonato micrítico y, finalmente, la disgregación de los granos arenosos (21). these measurements revealed the adverse effects of a $\mathrm{Zn}-\mathrm{Mg}$-F-silicate treatment applied in the nineteen sixties and recently re-applied despite advice to the contrary. In fact, such treatment hardened the stone surface only (2$3 \mathrm{~mm}$ depth) which, being very brittle, soon began to work loose and fall away at a dramatic pace. This decay mechanism was detected on element distribution maps plotted under a scanning electron microscope (SEM) in conjunction with energy dispersive spectroscopy (EDS) (Figure 6). The findings showed that silica diffusion led to the dissolution of the micritic carbonate matrix and ultimately to the disaggregation of the constituent grains of sandstone (21)

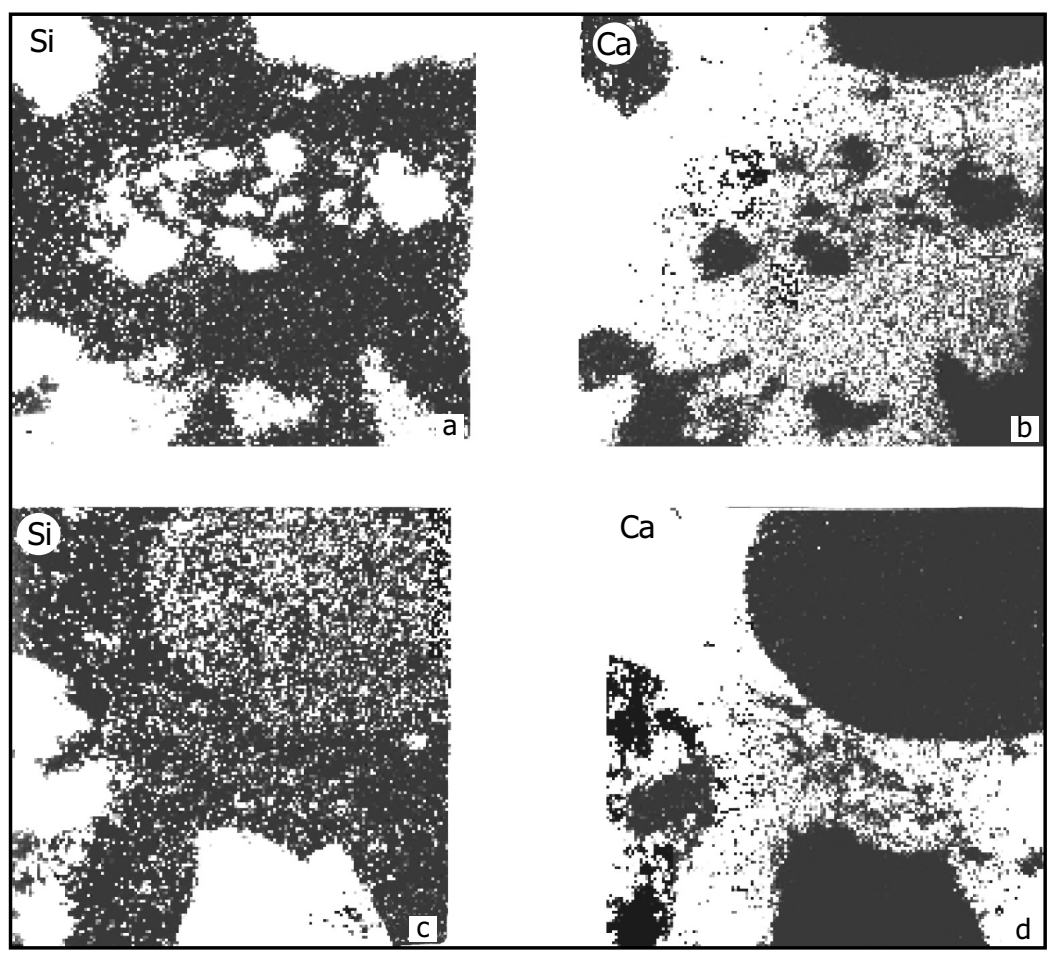

Figura 6. Mapas de la distribución elemental en la matriz de calcita de la arenisca tratada con silicato de Zn-Mg-F. Basílica de San Miguel de Pavía, en el norte de Italia (21). Obsérvese la sustitución de Si por Ca, como muestran las secuencias (a)-(b) y (c)-(d), realizadas, respectivamente, antes y después del tratamiento.

Figure 6. Maps showing the elemental distribution in the calcite matrix of sandstone treated with a Zn-Mg-F-silicate. From St. Michael's Basilica at Pavia, northern Italy (21); note the replacement of Ca with Si, as evidenced by sequences (a)-(b) and (c)-(d), respectively performed after and before treatment.

La observación mediante MEB combinada con los microanálisis de EDS es una metodología de uso extendido que se utiliza también para determinar la composición del mortero y la disposición espacial de sus componentes sólidos; a veces junto con tratamiento de imagen de la estructura, la textura y el sistema poroso (22).

De hecho, la caracterización química, mineralógica y mecánica de los morteros arqueológicos permite en muchos casos conocer la tecnología y la fecha de fabrica-
SEM observation coupled with EDS micro-analysis are tools also commonly used to ascertain mortar composition and spatial arrangement of its solid constituents, sometimes in conjunction with image processing of the structure, texture and pore system (22).

In fact, the chemical, mineralogical and mechanical characterization of archaeological mortars can often shed light on manufacturing technology and dating, weathe- 
ción, los procesos de meteorización y los tratamientos de conservación o restauración. Por otra parte, la cohesión interna insuficiente y la adherencia inadecuada se encuentran entre los efectos más importantes de la meteorización que pueden relacionarse con la composición y textura originales del mortero.

Cuando se ponen en práctica medidas de refuerzo (tales como la aplicación de lechadas o el llenado de huecos), las propiedades físicas del mortero moderno deberían ser muy afines a las del sustrato: el tipo de árido empleado y la relación conglomerante-árido inciden de forma especial en las propiedades mecánicas del mortero, ya que la dosificación de las mezclas afectan al comportamiento de retracción, a la porosidad y a la microestructura y, en consecuencia, al comportamiento hídrico, la resistencia mecánica y la durabilidad.

Un trabajo anterior (23) en el que se comparaban los procedimientos tradicionales (algunos de ellos cuestionados en el caso de de morteros con áridos de alto contenido de carbonatos) y las metodología innovadoras para el estudio de la tecnología de los morteros analizó varias categorías de ensayos: composición química y mineralógica, disolución en ácidos, ensayos mecánicos, índice de disgregación y análisis digital de imagen de láminas delgadas. Las ventajas e inconvenientes de cada uno se detallan más adelante, destacando su aplicabilidad al análisis de morteros y yesos arqueológicos.

Los datos mineralógicos, petrográficos, químicos y físicos recogidos (24) sobre el mortero total y el conglomerante demostraron que para construir la Torre Inclinada de Pisa se empleó sistemáticamente un mortero hidráulico de gran calidad (resistencia a la compresión media aproximada de $16 \mathrm{~N} / \mathrm{mm}^{2}$, contenido medio aproximado de $\mathrm{SiO}_{2}$ en el conglomerante del 29\%). Los resultados obtenidos (Figura 7) indican que el mortero se preparó mezclando cal muerta con arena y un suelo diatomáceo (relación $1: 1: 1 / 3)$.

Resulta sorprendente el hecho de que se aplicara una estrategia constructiva tan inusual a finales del siglo XII (primera fase de construcción de la torre) y que volviera a aplicarse sin cambios un siglo más tarde (segunda fase de construcción), haciendo que sea prácticamente imposible distinguir ambos morteros. Por otra parte, no se han encontrado en los edificios medievales de Lucca (ciudad a menos de veinte kilómetros de Pisa) ninguna muestra de esta técnica.

Una inspección visual de los materiales procedentes de ruinas de la medieval Torre Cívica de Pavía, que se derrumbó de repente en 1989, mostró que el mortero se había desprendido de los muros estructurales de ladrillo, mientras que los ensayos mediante MEB del mortero inte- ring processes and preservation or restoration treatments. Insufficient inner cohesion and poor bonding, in turn, are among the most important effects of weathering that can be related to the original composition and texture of mortar.

When reinforcement measures (such as grouting or filling of lacunae) are implemented, the physical properties of the modern mortar should match those of the substrate very closely: the type of aggregate used and the binder/aggregate ratio especially have an impact on the mechanical properties of the mortar, because mix batching affects shrinkage behaviour, porosity and microstructure, and consequently water storage and transport, mechanical strength and durability.

A prior comparative evaluation (23) of traditional procedures (some of which are questioned for mortars containing carbonate aggregate) and innovative methodologies for studying mortar technology explored various categories of tests: chemical and mineralogical composition, acid dissolution, mechanical tests, stained disaggregation index and thin section digital imaging. The advantages and drawbacks of each are discussed below, highlighting their applicability to the analysis of archaeological mortars and plasters.

Mineralogical, petrographical, chemical and physical data collected (24) on bulk mortar and the binder showed that a high quality hydraulic mortar was consistently used to build the leaning tower of Pisa (average compressive strength of around $16 \mathrm{~N} / \mathrm{mm}^{2}$, average binder $\mathrm{SiO}_{2}$ content about 29\%). The results obtained (Figure 7) suggest that the mortar was prepared by mixing slaked lime with sand and a diatomaceous soil (relative ratio 1:1:1/3).

That such an unusual building strategy was implemented in the late twelfth century (1st stage of tower construction) and applied, unchanged, a full century later (2nd stage of construction), making the mortars from the two periods nearly indistinguishable, is astonishing. Moreover, no example of this technique has been found in the Medieval buildings in Lucca (a town not more than twenty kilometres from Pisa).

A visual inspection of the materials from the ruins of the Medieval Civic Tower of Pavia, which collapsed suddenly in 1989, showed that mortar had become detached from the structural brick walls, while SEM studies of the inner mortar revealed poor binder/aggregate bonding (Figure 
rior revelaron una deficiente adherencia entre el conglomerante y el árido (Figura 8). Estas condiciones se consideraron como cruciales para el derrumbe (25).
8). These conditions were judged to have been crucial to the collapse (25).

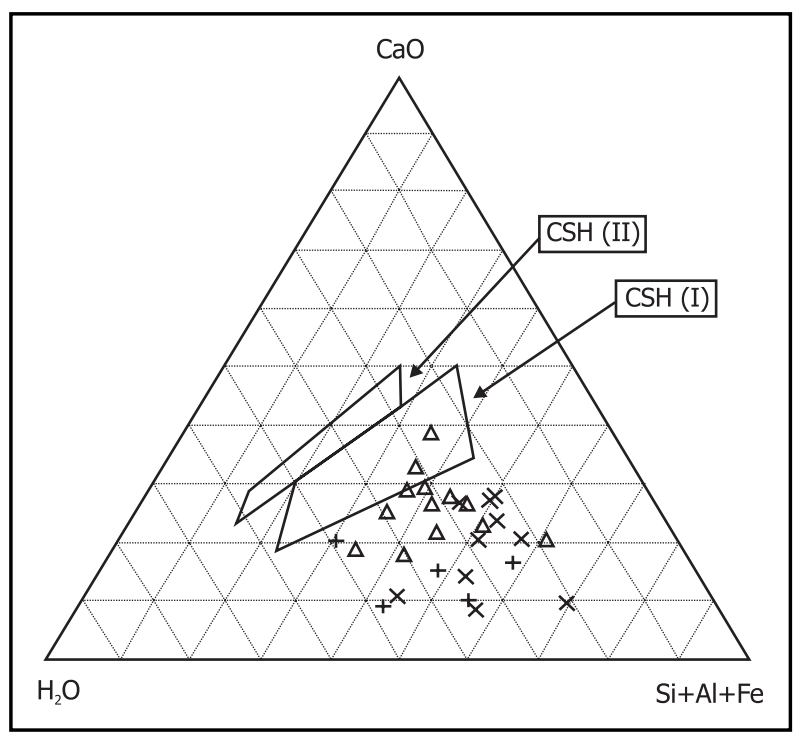

Figura 7. Composición química (porcentaje molar) de la fase amorfa del conglomerante de los morteros de la Torre de Pisa (24). CSH I y II indican variaciones en la composición de los compuestos de CSH.

Muestras tomadas en los cimientos $(\Delta)$, primer nivel de construcción (1173-78) (x) y segundo nivel 1272-78 (+).

Figure 7. Chemical composition (molar percentage) of the amorphous phase of the binder in Pisa tower mortars (24): CSH (I and II) denote compositional variations in CSH compounds.

Samples from foundations $(\Delta)$, first construction stage (1173-78) $(x)$ and second stage (1272-78) $(+)$.

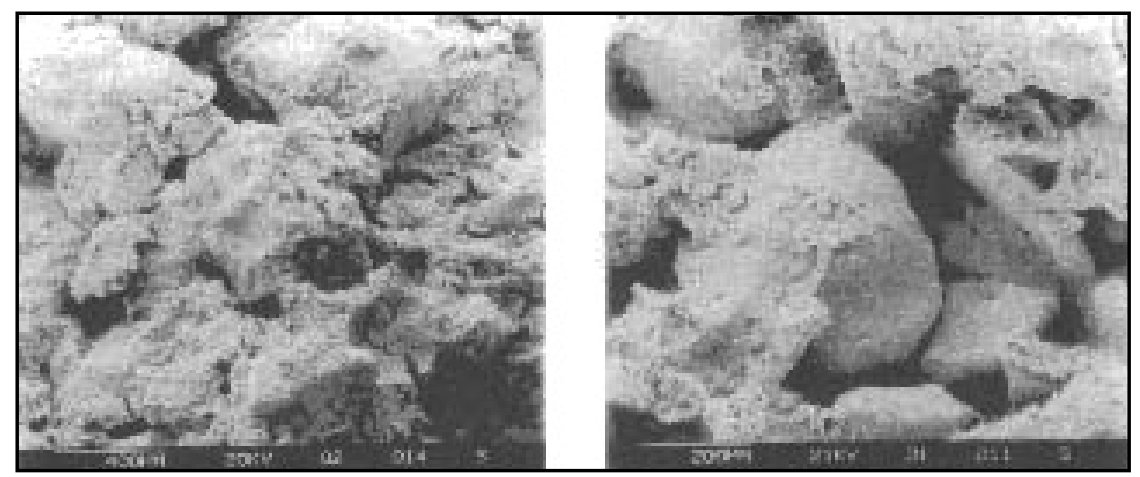

Figura 8. Saltación del mortero en la fábrica de ladrillo de la Torre Cívica de Pavía, norte de Italia (25). Obsérvense las variaciones en la cantidad de conglomerante.

Figure 8. Mortar disaggregation in the brick masonry of the Civic Tower of Pavia, northern Italy (25). Note the variations in the amount of binder.

La MEB detectó asimismo alteraciones causadas por microorganismos, otro fenómeno que debería identificarse. La observación detenida de las pátinas que cubrían las columnas adosadas de granodiorita situadas en la base de la Torre de Pisa (26) mostró que estaban colonizadas por hongos y que los microorganismos también se habían introducido en los planos de exfoliación de las láminas de mica y clorita (Figura 9). Su presencia aumentaba el tamaño de los poros e intensificaba la lajación.
SEM also detected alterations caused by micro-organisms, another development that should be identified. Detailed observations of the decay patinas coating the granodiorite half-columns around the base of the Pisa tower (26) showed them to be colonized by fungi; microorganisms had also penetrated the cleavage planes in mica-chlorite lamellae (Figure 9). Their presence increased pore size and intensified spalling. 
Un interesante estudio sobre la lajación en esculturas calizas de Egipto (27) se basó en ciclos de humedad-sequedad y en la consiguiente expansión-contracción de las fibras de sepiolita y paligorskita situadas a lo largo de los microplanos de estratificación. Se observó expansión en las imágenes ampliadas (Figura 10) obtenidas mediante un microscopio electrónico de barrido ambiental (MEBA), habiéndose tomado medidas para evitar artefactos provocados por el vacío en el tubo del microscopio. Como resultado de estas conclusiones se recomendó el control riguroso de la humedad relativa en las salas de almacenamiento de los museos para garantizar la conservación adecuada de estas obras de arte.
An interesting study on spalling in Egyptian limestone sculptures (27) was based on wet-dry cycle experiments and the concomitant "osmotic" swelling/shrinking of sepiolite-palygorskite fibres located along micro-bedding planes. Expansion was observed under high magnification (Figure 10) using an environmental scanning electron microscope (ESEM), where measures had been taken to avoid artefacts caused by the vacuum in the microscope tube. The result of these findings was a recommendation for strict control of relative humidity in museum storage rooms to ensure the proper conservation of these works of art.

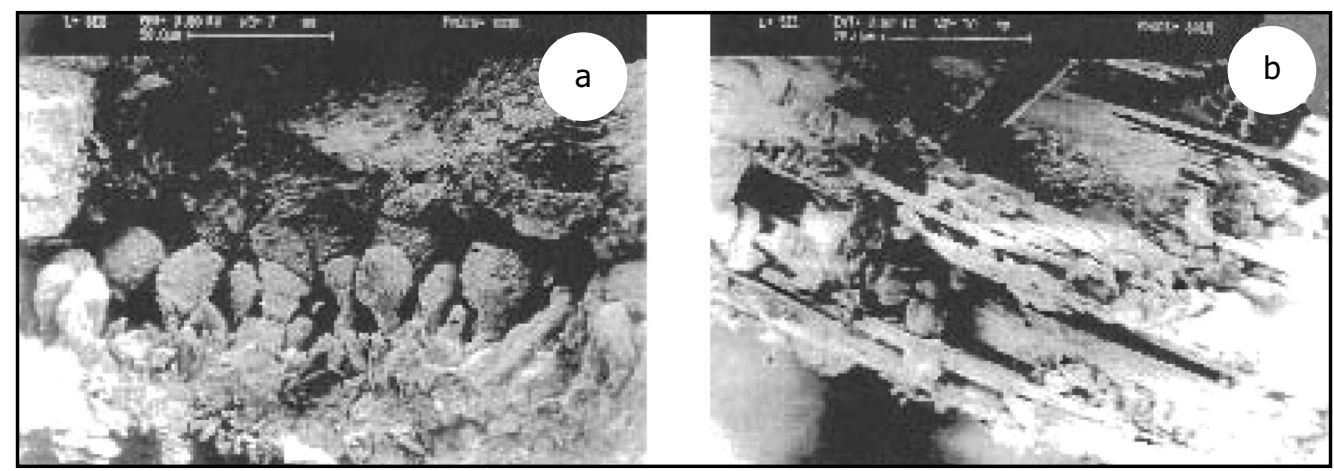

Figura 9. (a) Detalle de pátina con gran porosidad interna debido a la presencia de una colonia de hongos.

(b) Hongos penetrando en los planos de exfoliación de una lámina de biotita cloritizada. Columna adosada de granodiorita en la base de la Torre de Pisa (26).

Figure 9. (a) Detail of patina with high internal porosity due to the presence of a fungal colony.

(b) Fungi penetrating the exfoliation (cleavage) planes of a chloritized biotite lamella. Granodiorite half-column at the base of Pisa tower (26).

Una ventaja de la tomografía computerizada es la rapidez con que se generan imágenes tridimensionales de la estructura interna de un material (28), localizando las heterogeneidades (Figura 11c), tales como inclusiones, diferencia de componentes, poros, huecos, formas de fractura o difusión de líquidos, que influyen en la absorción de agua, la resistencia mecánica, etc. Además, la distribución de impurezas como los minerales arcillosos (Figura 11a, b), podría acelerar los mecanismos de degradación. Esta técnica también permite comprobar la eficacia de los productos químicos de consolidación basándose en su penetración y endurecimiento en distintos momentos, tanto durante como después de la aplicación.

Los componentes minerales arcillosos de la piedra, tanto si se encuentran dispersos por toda la matriz como si se encuentran llenando huecos, pueden desempeñar una importante función en los procesos de degradación (29). La expansión-contracción y la agregación-disgregación producidas como consecuencia de la interacción de las partículas arcillosas con el agua y otros líquidos salados pueden provocar el fallo estructural. La cristalización de la
One of the advantages of computerized X-ray tomography is its rapid generation of 3-D images of a material's inner structure (28), locating heterogeneities (Figure 11,c) such as inclusions, differences in constituents, pores, voids, fracture patterns or fluid diffusion, which impact water sorption, mechanical strength and others; furthermore, the distribution of impurities such as clay minerals (Figure 11a, b) may accelerate decay mechanisms. This technique also features the possibility of testing the effectiveness of consolidating chemicals on the grounds of their penetration and hardening at different test times during and after application.

Clay mineral constituents in stone, either scattered throughout the matrix or filling voids, can play an important role in decay processes (29). Swelling-shrinking and aggregation-disaggregation occurring as a result of the interaction of clayey particles with water and other salty fluids can cause structural breakdown. Salt crystallization, which depends on fluid transfer, evaporation and ion concentration in the solutions, may be affected by 
sal, que depende del transporte y la evaporación de líquidos y de la concentración iónica de las soluciones, puede verse afectada por la reactividad de los minerales arcillosos, resultando la piedra gravemente dañada (38). clay mineral reactivity, resulting in significant stone damage (38).

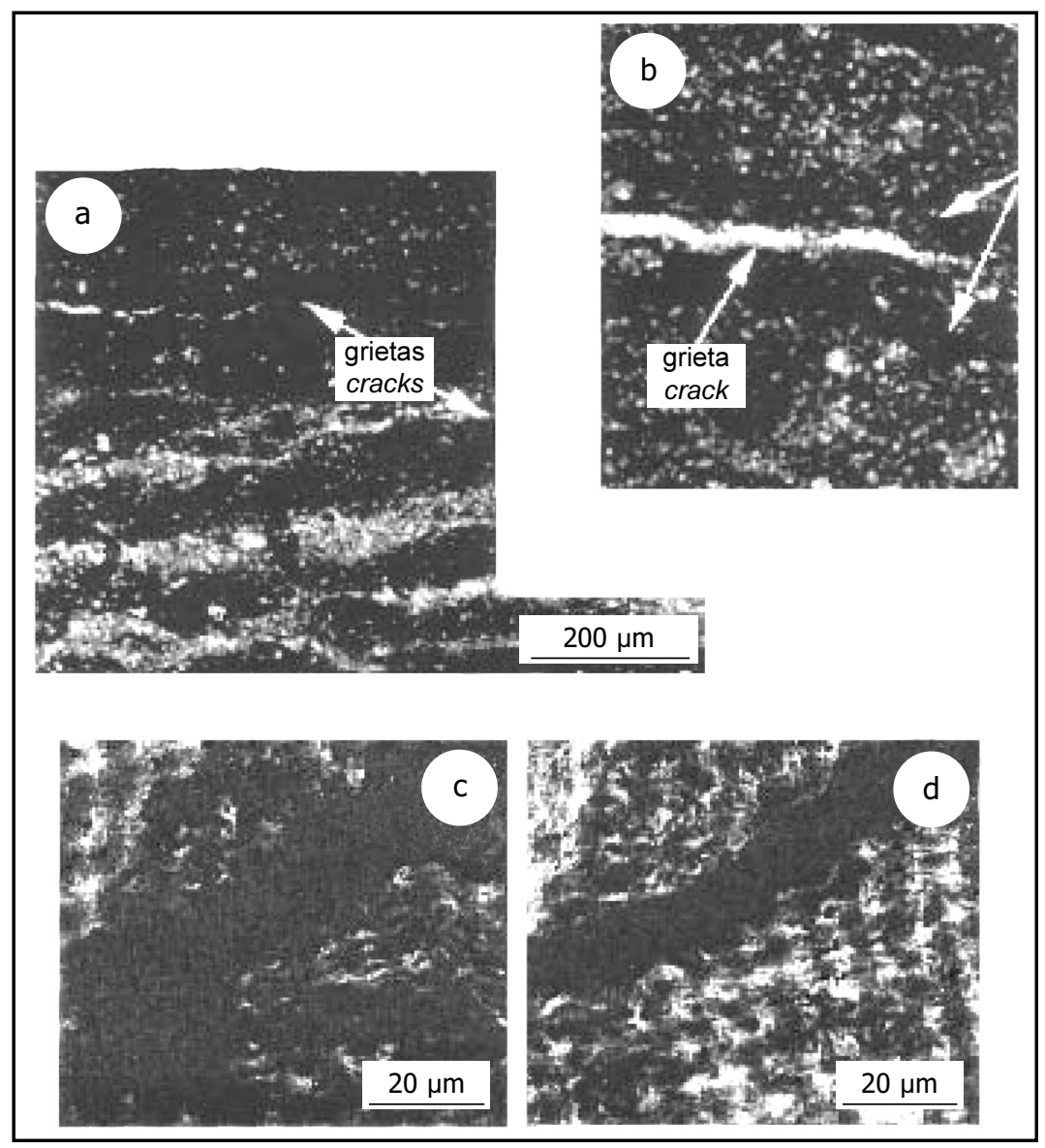

Figura 10. Caliza expandida y agrietada (estela egipcia) tras inmersión en agua (27). (a) y (b) Observaciones con MEBA antes y después de la inmersión, respectivamente. (c) y (d) Arcilla antes y después de la inmersión, respectivamente.

Figure 10. Swollen and cracked limestone (Egyptian stela) after immersion in water (27). (a) and (b): ESEM observations before and after immersion, respectively; (c) and (d): clay before and after wetting, respectively.

El ennegrecimiento, cuya distribución sobre la superficie y composición son típicas de cada lugar, es uno de los tipos más visibles de daños que afectan al patrimonio construido de las zonas urbanas. Las partículas carbonosas emitidas mediante procesos de combustión desempeñan una función determinante, siendo el carbón el segundo elemento antropogénico más abundante, después del azufre, en las capas de hollín.

Por tanto, la determinación y evaluación de las especies de carbón de distintas procedencias son fundamentales para identificar los mecanismos de deterioro y definir las estrategias de protección o conservación, así como para predecir las tendencias de deposición de numerosos contaminantes.
Blackening is one of the most visible types of damage affecting the built heritage in urban areas; surface pattern distribution and composition are typical of each site. Carbonaceous particles emitted by combustion processes play a key role, with carbon being the second most abundant anthropogenic element, after sulphur, in the layers of soot.

Therefore, speciation and evaluation of the carbon species originating from different sources are crucial to identifying the damage mechanisms and defining protection or preservation strategies, as well as to predicting multipollutant deposition trends. 
El carbono total (CT) incluye el carbono carbonatado (CC), especialmente característico del substrato (piedra y mortero) y el carbono no carbonatado (CNC), originado por la deposición de partículas atmosféricas. A su vez, el CNC consta de carbono orgánico (CO), de origen natural y antropogénico tanto principal como secundario, y de carbono elemental (CE), resultado de la deposición de aerosoles derivados de la combustión (hollín). La evaluación del CNC, y en especial del CE, es por tanto necesaria para determinar si el carbono deriva del sustrato pétreo o si se debe a la deposición de partículas antropogénicas.

Recientemente se han obtenido datos precisos y reproducibles sobre fracciones de carbono en las costras y manchas negras de edificios históricos europeos (30) usando un procedimiento químico-térmico (31) que ha permitido llenar el vacío existente de métodos analíticos adecuados y fiables.
Total carbon (TC) comprises carbonate carbon (CC), essentially intrinsic in the underlying materials (stone and mortar), and NCC (non-carbonate carbon), originating from atmospheric deposition; NCC in turn consists in organic carbon (OC), of both primary and secondary natural and anthropogenic origin, and elemental carbon (EC), the result of the deposition of combustion-derived aerosols (soot). The evaluation of NCC, and particularly of $E C$, is therefore necessary to ascertain whether the carbon derives from the stone substrate or is due to anthropogenic particle deposition.

Accurate and reproducible data on carbon fractions in black crust and soiling on European heritage buildings (30) have recently been obtained using a chemical-thermal procedure (31) that has helped to fill the current gap in suitable and reliable analytical methods.

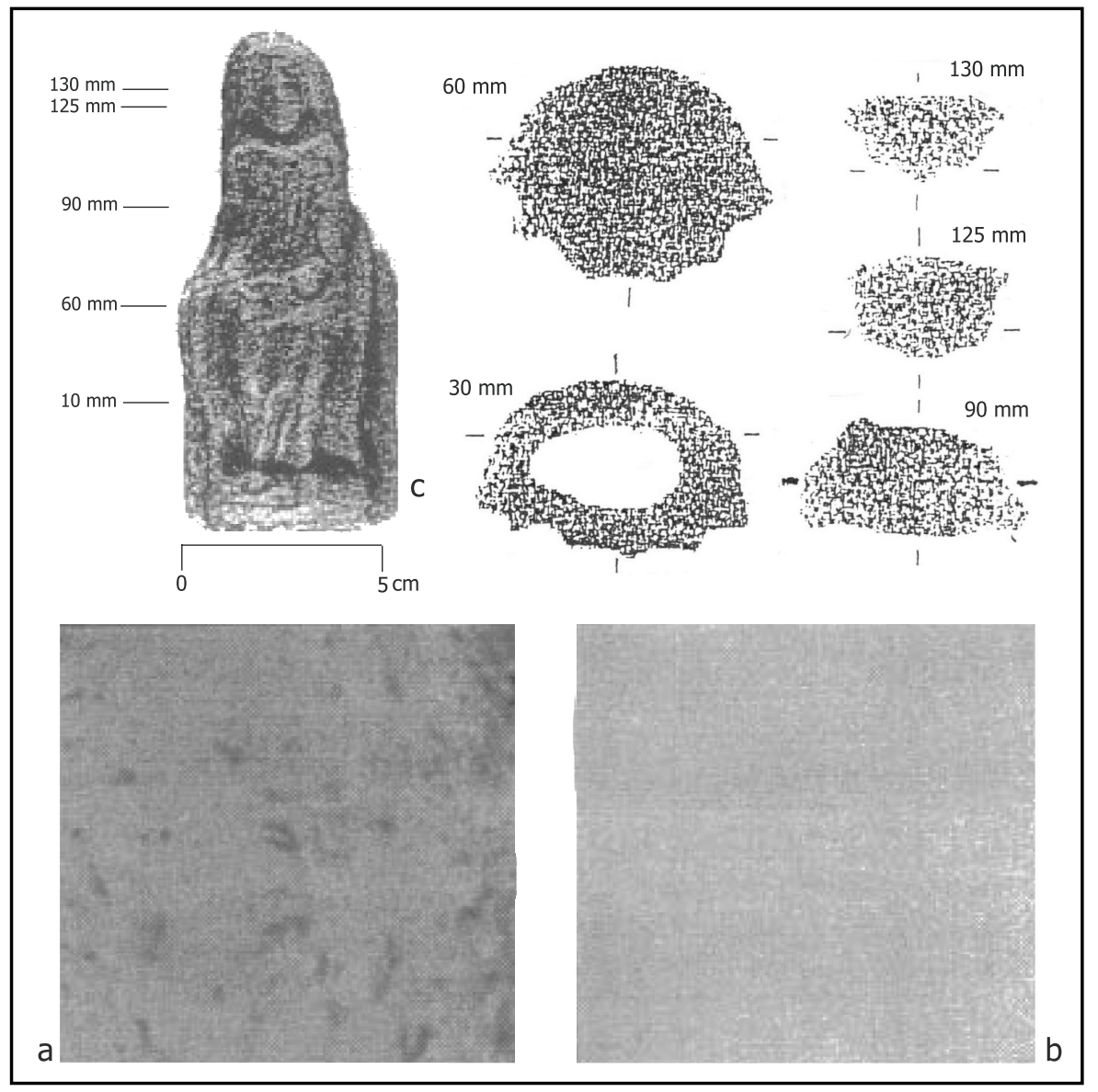

Figura 11. Imágenes de arenisca calcárea (a) y de mármol de Carrara (b) obtenidas mediante tomografía computerizada (TC). (c) Imagen obtenida mediante TC de estatua votiva de terracota a distintos niveles de la figura, mostrando las heterogeneidades internas atribuidas a las impurezas o a las inclusiones (partículas de productos de refuerzo). Las imágenes correspondientes a los niveles entre $125 \mathrm{~mm}$ y 130 $\mathrm{mm}$ contienen zonas con distintas tonalidades de gris, probablemente procedentes de algún material usado para ligar los fragmentos.

Figure 11. X-ray computerized tomographic (CT) images of a calcareous sandstone (a) and Carrara marble (b). (c) CT-image of a votive terracotta statue at different levels of the figure, showing the internal heterogeneities attributed to impurities and/or inclusions (reinforcement product particles); the images corresponding to levels $125-130 \mathrm{~mm}$ contain zones with different grey hue, probably from a material used to bond fragments. 
En lo referente a la alteración química debida a la contaminación atmosférica, la influencia de la lluvia (duración, continuidad e intensidad) parece cumplir una importante función en relación con los daños a la superficie de la piedra.

Se ha observado (datos no publicados) un caso interesante en la dolomía (pietra di Angera) empleada para construir las balaustradas del patio del edificio principal de la Universidad de Pavía. Se analizaron mediante difracción por rayos $\mathrm{X}$ muestras selladas de eflorescencias tomadas poco después de lluvias intensas y se halló sulfato de magnesio heptahidratado (epsomita), una fase transitoria que se convierte rápidamente en sulfato de magnesio hexahidratado, que es relativamente más estable.

Los estudios realizados en el laboratorio (32) sobre la alterabilidad de las piedras calcáreas (usadas como materiales de construcción en Francia y España) frente a la niebla salina mostraron que, aunque las distintas técnicas eran complementarias entre sí, las imágenes láser por ultrasonidos proporcionaban una visión más amplia de la evolución cualitativa y cuantitativa de la degradación de la superficie.

La investigación realizada sobre la superficie de la travertina de la fachada de San Pedro del Vaticano en Roma (33) es un buen ejemplo de estudio exhaustivo, especialmente en lo referente a las medidas de limpieza adecuadas.

Durante la restauración llevada a cabo por la Fabbrica di San Pietro, que contó con ENI-Technologies como socio científico y tecnológico, se formuló una descripción detallada de la composición de la fase y de la morfología de los productos de degradación, que se publicó en el año 2000 con motivo del Año Jubilar.

El informe destacaba que las metodologías diagnósticas empleadas y la información conseguida, junto con los resultados de los ensayos de laboratorio, habían permitido seleccionar y poner en práctica los procedimientos de limpieza más adecuados.

La inspección visual de la "piel" de la piedra permitió hacer algunas observaciones interesantes: (i) la costra negra estaba presente principalmente en zonas protegidas de la lluvia; (ii) las áreas algo menos resguardadas tenían color grisáceo; (iii) los tonos más claros se encontraban en zonas donde la lluvia limpiaba la piedra de forma rutinaria.

Se extrajeron muestras de la "piel" exterior de la piedra usando una pequeña taladradora con broca de diamante y luego se fijaron en resina epoxi y se desbastaron. Se documentaron con vídeo y fotografías las ubicaciones de las muestras, que posteriormente fueron catalogadas.
In the context of chemical alteration due to air pollution, the impact of rain (duration, continuance and intensity) may play an important role in stone surface damage.

An interesting development has been observed (unpublished data) on the dolostone ("pietra di Angera") used to build the courtyard balustrades in Pavia University's Main Building. Sealed samples of efflorescence taken shortly after intensive rains analysed by $X$-ray diffractometry were found to contain hepta-hydrate Mg-sulphate (epsomite), a transitional phase that is quickly converted into the relatively more stable hexa-hydrate $\mathrm{Mg}$-sulphate.

Laboratory studies conducted (32) on the alterability of calcareous stones (used as building materials in France and Spain) exposed to saline fog, combining and comparing the results of weight-loss, acoustic laser propagation and image processing, showed that while the various techniques complemented one another, the ultrasonic laser images provided a fuller view of the qualitative and quantitative evolution of surface degradation.

The research conducted on the surface of travertine stone on the facade of St. Peter's (Vatican) in Rome (33) constituted an exhaustive study, in particular from the standpoint of appropriate cleaning measures.

A detailed description of phase composition and morphology of decay by-products was formulated on the occasion of the restoration performed by the "Fabbrica di San Pietro", with ENI-Technologies as scientific and technological partner: the results were published in Jubilee Year 2000.

The report stressed that the diagnostic methodologies deployed and the information acquired, in conjunction with the results of laboratory tests, made it possible to select and implement the most appropriate cleaning procedures.

Visual inspection of the stone "skin" led to some interesting observations: (i) black crust was mainly present in areas protected from the rain; (ii) moderately sheltered areas were greyish in colour; (iii) the lightest shades were found in areas where the stone was routinely washed by rain.

Samples of the outer "skin" of the stone were removed using a small, diamond bit drill, then embedded in epoxyresin and polished. Sample locations were documented on video and in photos and subsequently catalogued. 
Se aplicó el método de Rietveld (ajuste del perfil completo) en el análisis cuantitativo por DRX de las distintas fases. Para los microanálisis químicos puntuales se empleó la tecnología MEB combinada con EDS. También se usaron la termogravimetría (TG) a escala microscópica y la espectrometría de infrarrojos por transformada de Fourier (FIIR).

Puesto que las técnicas analíticas anteriormente mencionadas no podían, por sí solas, proporcionar una definición cuantitativa completa de los distintos componentes (fases cristalinas y amorfas, partículas orgánicas y de polvo, etc.), los resultados obtenidos con ellas se combinaron y se comprobó la precisión de los resultados comparándolos con una muestra estándar cuya composición se conocía. Este procedimiento integral ofreció resultados de composición fiables para las zonas de distintos colores:
The Rietveld procedure (full-profile fitting) was applied in the $X$-ray diffractometry-based quantitative analysis of the constituent phases. SEM technology, in conjunction with EDS, was used for chemical "spot" microanalyses. Microscale thermal gravimetry (TG) and reflection mode Fourier transform infrared spectrometry (FIIR) were also performed.

Inasmuch as the above analytical techniques, when taken alone, were unable to provide a complete quantitative definition of the various constituents (i.e., crystalline and amorphous phases, organic and dust particles, and so on), their findings were combined and the accuracy of the results verified against a standard sample of known composition. This comprehensive procedure yielded reliable compositional results for the differently coloured areas:

\begin{tabular}{|c|c|c|c|c|c|c|}
\hline $\begin{array}{c}\text { Color } \\
\text { Colour }\end{array}$ & $\begin{array}{c}\text { Calcita } \\
\text { Calcite }\end{array}$ & $\begin{array}{c}\text { Yeso } \\
\text { Gypsum }\end{array}$ & $\begin{array}{c}\text { Bassanita } \\
\text { Bassanite }\end{array}$ & $\begin{array}{c}\text { Weddellita } \\
\text { Weddellite }\end{array}$ & $\begin{array}{c}\text { Orgánico } \\
\text { Organic }\end{array}$ & $\begin{array}{c}\text { Inorgánico } \\
\text { Inorganic }\end{array}$ \\
\hline negro / black & 3 & 66 & 6 & 5 & 4 & 16 \\
\hline gris / grey & 20 & 45 & 10 & 6 & 3 & 16 \\
\hline color claro / light & 84 & 2 & - & 3 & 1 & 10 \\
\hline
\end{tabular}

Las observaciones mediante MEB de la costra negra reveló la existencia de distintas capas superficiales de hasta $1 \mathrm{~mm}$ de grosor (Figura 12a) con una secuencia typical travertine $\rightarrow$ gypsum, mientras que no se observó ninguna capa de degradación en las zonas de color claro. Esto no significa, sin embargo, que estas zonas estuvieran protegidas del deterioro. De hecho, al inspeccionarlas más detenidamente se hallaron algunos puntos oscuros localizados (Figura 12b) que penetraban en la porosidad abierta de la piedra. En las zonas grises se daban situaciones intermedias.

Las capas de la superficie degradada contenían cantidades variables de partículas orgánicas e inorgánicas generadas, respectivamente, por los gases de los vehículos y la suciedad (Figura 13).
SEM observations of black crust revealed the existence of distinct superficial layers up to $1 \mathrm{~mm}$ thick (Figure 12,a) with a typical travertine $\rightarrow$ gypsum sequence, whereas no degradation layer was observed in the light coloured areas. This does not mean, however, that such areas were protected from deterioration: in fact, localized dark spots (Figure 12,b) that penetrated the stone's open porosity were found under close inspection. Intermediate situations were found in grey areas.

The degraded surface layers contained varying amounts of organic and inorganic particles generated by vehicle exhaust and dirt, respectively (Figure 13).

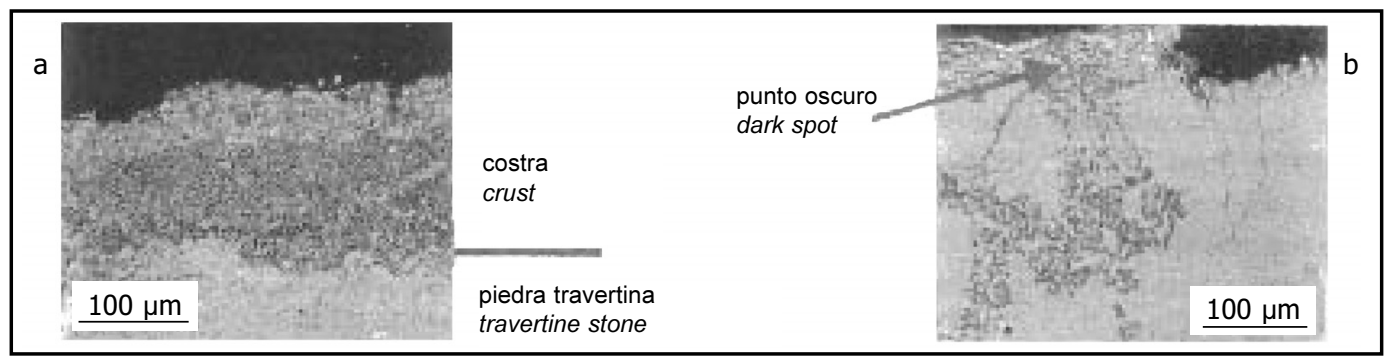

Figura 12. Micrografías obtenidas mediante MEB de la costra que cubre la travertina de la fachada de la Catedral de San Pedro de Roma (33). (a) Secuencia típica de travertina a sulfato en una costra negra.

(b) Puntos oscuros de origen antropogénico en una zona de color claro

Figure 12. SEM micrographs of crust covering the travertine stone on the façade of St. Peter's Cathedral in Rome (33). (a) Typical sequence travertine $\rightarrow$ sulphate in a black crust.

(b) Dark spots of anthropogenic origin within a light-coloured area. 
Se dio prioridad a las metodologías y procedimientos de limpieza que tuvieran un impacto menor en la piedra. Se eligió la tecnología JOS (tradución en español de: patented swirling vortex), ya que permitía quitar la costra sin dañar la superficie de la piedra (figura 14a). Otras tecnologías de limpieza no sólo no lograron quitar completamente la costra de yeso (Figura 14b) sino que dañaron la superficie de la travertina (Figura 14c).
Priority was given to cleaning methodologies and procedures having a minimal impact on the stone. JOS technology (patented swirling vortex) was chosen, for it is able to remove crust without damaging the underlying stone surface (Figure 14,a). Other cleaning technologies not only proved to be unable to completely remove the gypsum crust (Figure 14,b) but were found to damage the travertine surface (Figure14,c).

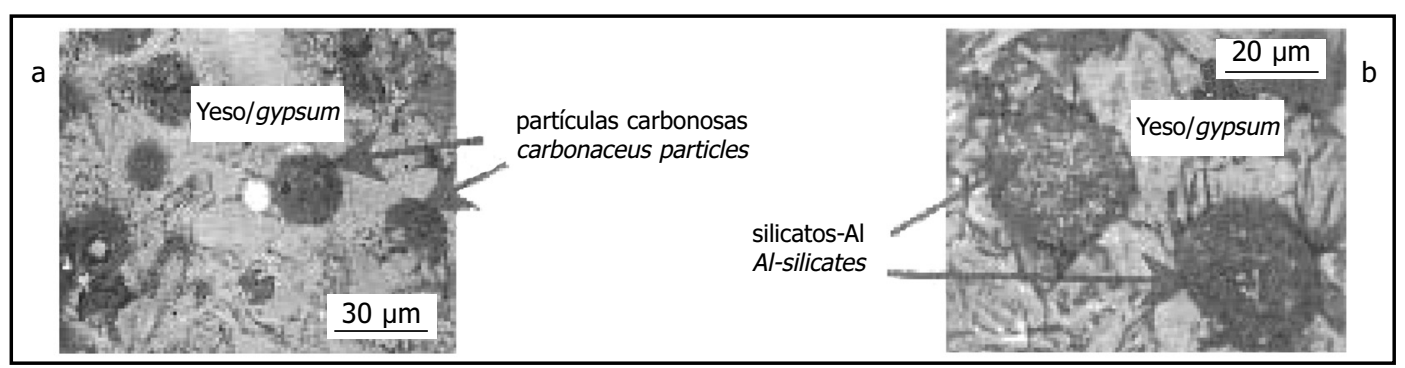

Figura 13. Micrografías obtenidas mediante MEB mostrando partículas carbonosas (a) y de silicato de aluminio (b) en la costra. Catedral de San Pedro de Roma (33).

Figure 13. SEM micrographs showing carbonaceous (a) and Al-silicate (b) particles in crust. St. Peter's Cathedral in Rome (33).

Recientemente se ha sugerido (34) una innovadora técnica basada en la pulverización de hielo seco $\left(\mathrm{CO}_{2}\right)$ para quitar las pátinas negras (que contienen alrededor de un $10 \%$ de yeso) de los elementos arquitectónicos (columnas, sillerías, soportales y cornisas exteriores de la logia inferior de la fachada de la Catedral de Pavía, en el norte de Italia) de mármol de Crevola, una dolomía blanquecina y muy compacta. Este tratamiento restauraría la porosidad original, favoreciendo por tanto una evaporación más uniforme.
An innovative technology based on "dry-ice" $\left(\mathrm{CO}_{2}\right)$ spraying has recently been suggested (34) for removing black patinas (containing about 10\% gypsum) from architectural elements (columns, ashlars, arcades and outer cornices on the lower loggia of the facade of Pavia cathedral, northern Italy) made from so-called "Crevola" marble, a highly compact whitish dolostone. Such treatment would restore the original porosity, thereby favouring more uniform evaporation.

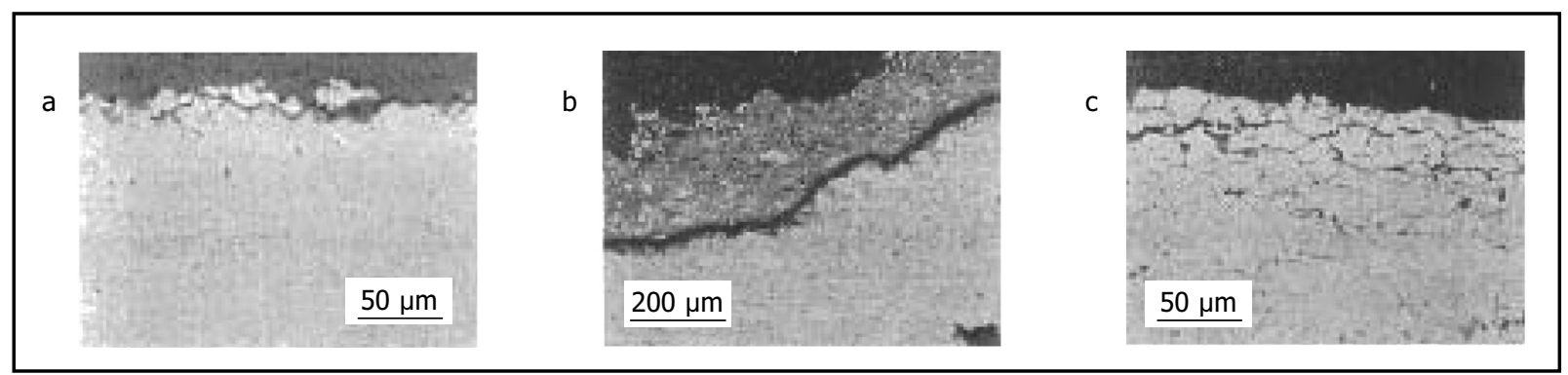

Figura 14. Micrografías obtenidas mediante MEB mostrando el efecto de distintos procedimientos de limpieza sobre la superficie de la travertina. (a) JOS, (b) láser y (c) chorro de arena. Catedral de San Pedro de Roma (33).

Figure 14. SEM micrographs showing the effect of different cleaning procedures on the travertine stone surface:

(a) JOS, (b) laser and (c) sandblasting; St. Peter's Cathedral in Rome (33).

La exfoliación de estas pátinas superficiales se ha observado principalmente allí donde la piedra tiene un acabado abujardado. En estas zonas, la piedra ha resultado ser friable más que cohesivo, presentando un aspecto termoclástico.
Detachment of these superficial patinas has mainly been observed where the stone had been "bush hammer" finished: in these areas, the stone was found to be friable rather than cohesive, with a thermoclastic appearance. 


\section{COMENTARIOS FINALES}

El estudio de la piedra natural ( $y$ de otros materiales de construcción como el mortero y el yeso) precisa del uso de técnicas analíticas y de ensayo empleadas en las ciencias de la tierra y de los materiales. Un enfoque interdisciplinario como éste proporciona información sobre el tipo y el origen del deterioro, así como las formas en que se ha trabajado la piedra (Figura 15).

\section{CONCLUDING REMARKS}

The study of natural stone (and other building materials such as mortar and plaster) calls for the deployment of analytical and testing techniques used in geo-and materials science. Such an interdisciplinary approach provides information on the nature and origin of decay and working practices (Figure 15).

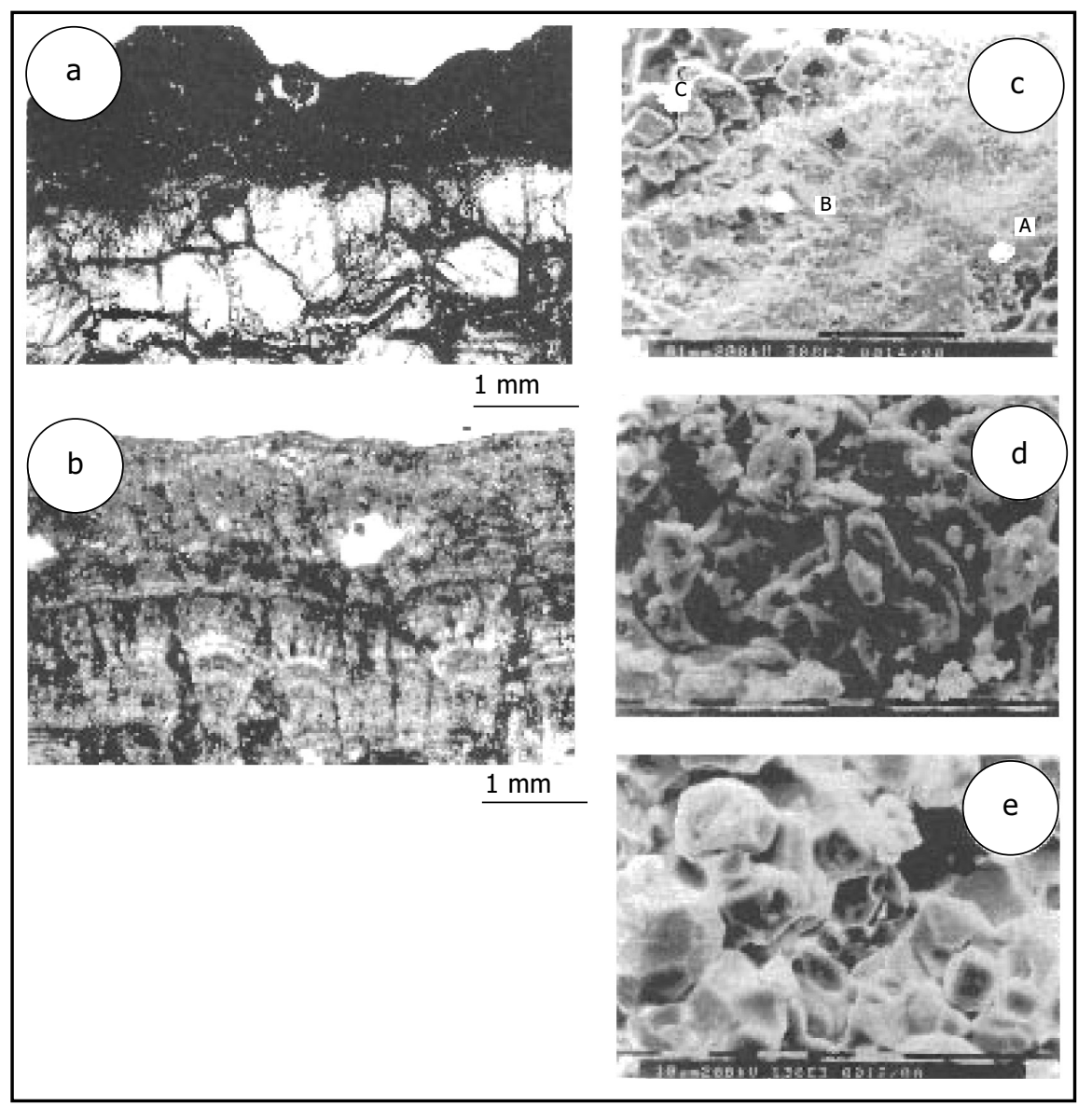

Figura 15. Ejemplos de heterogeneidades de composición y textura encontrados en productos de la degradación de la fábrica en la Torre de Pisa (26 y 43). Láminas delgadas bajo microscopio petrográfico: (a) Costra negra amorfa sobre piedra fracturada. Obsérvese la penetración de los productos de lixiviación en las microfisuras. (b) Costra grisácea microcristalina sobre microestromatolito de varias capas. Observaciones mediante MEB: (c) A = pátina de oxalato; $\mathrm{B}=$ zona mixta; C = granos de calcita (piedra). (d) Láminas de yeso en costra negra. (e) Disgregación de granos de calcita en la superficie de mármol alterado por insolación.

Figure 15. Examples of compositional and textural heterogeneities encountered in decay by-products on Pisa tower masonry (26), (43). Thin sections, under a petrographic microscope: (a): amorphous black crust on a fractured stone; note the leaching products permeating the micro-fissures; (b): greyish micro-crystalline crust on a multilayer micro-stromatolite SEM observations: (c): $A$ = oxalate patina, $B=$ mixed zone, $C=$ calcite grains (stone). (d): gypsum lamellae in a black crust; (e): disaggregation of calcite grains on the surface of a marble damage by insolation..

El comportamiento de la piedra al estar expuesta a los agentes ambientales depende de su orientación (véase tabla 1) y de los elementos de construcción: cimientos, basamento y estructuras exteriores (muros, columnas, arcos, bóvedas, cornisas) o interiores (salas, escaleras).
Stone performance when exposed to environmental agents depends on the direction faced (see table 1) and building element involved: foundations, basement, outdoor (walls, columns, arches, vaults, cornices) or indoor structures (rooms, staircases). 
Tabla 1 / Table 1

Superficie $\left(\mathrm{m}^{2}\right)$ de piedra de la Torre de Pisa afectada por los distintos tipos de degradación superficial, según la orientación (13)

Area $\left(m^{2}\right)$ of Pisa tower stones affected by various types of superficial decay, by direction of exposure (13)

\begin{tabular}{|l|c|c|c|c|}
\hline Tipo / Typology & Este / East & Norte / North & Oeste / West & Sur / South \\
\hline costra negra / black crust & 238 & 200 & 180 & 310 \\
\hline saltación / disaggregation & 293 & 350 & 342 & 418 \\
\hline lajación / spalling & 5 & 5 & 5 & 5 \\
\hline fisuras y grietas / fissures, cracks & 1040 & 1115 & 923 & 963 \\
\hline
\end{tabular}

Además, deberían estudiarse las características y propiedades de la piedra en distintos momentos de su ciclo de vida: al ser extraída, al ser cortada y esculpida y tras su colocación en edificios (35).

Estudiar la "anatomía, fisiología y patología" de las piedras a lo largo de tanto tiempo puede resultar bastante complejo, ya que las formas y las velocidades de deterioro están influidas por sus propiedades intrínsecas (36) y por agentes extrínsecos ( 37 y 38). Por ejemplo, se considera que los distintos tipos de ennegrecimiento están estrechamente relacionados con la composición y la textura del sustrato de la piedra y su posible edad; aunque este supuesto ha sido cuestionado (39).

Debería prestarse especial atención a la importancia de la estructura porosa y a la textura de la piedra durante el proceso de meteorización (40), así como a las causas y consecuencias de los cambios de volumen relacionados con el deterioro de los materiales de construcción (41).

La investigación sobre la piedra se ha visto a menudo obstaculizada por la falta de métodos analíticos no destructivos con los que pudiera verse el interior de la piedra.

Algunos ensayos no destructivos analizan el comportamiento de ciertas propiedades físicas (velocidad de transmisión de ultrasonidos, conductividad eléctrica, radar de impulsos electromagnéticos) en el interior o en la superficie de los materiales. En el caso de la piedra, este comportamiento puede correlacionarse con las características petrofísicas (composición mineral, anisotropía, porosidad, fisuras, dislocaciones) y el grado de deterioro. En este sentido debe decirse que los ensayos térmicos y mecánicos pueden dañar los materiales.

A la hora de emplear estas técnicas deben tenerse en cuenta los aspectos siguientes: (i) tipo de señal (natural o artificial); (ii) contacto, si procede, entre los sensores y la piedra; (iii) procedimientos de trabajo (reflexión, impulso del eco, transmisión sobre la superficie de la piedra o a través de ésta); (iv) una o varias señales desde todas las posiciones posibles (tomografía). La principal dificultad es
Moreover, stone characteristics and properties should be studied at different times in its life cycle: when quarried, when sized and sculpted, and after placement in buildings (35).

Studying the "anatomy, physiology and pathology" of stones through such a "journey" may be rather complex; deterioration pathways and rates are influenced by their intrinsic properties (36) and extrinsic agents both (37) (38). For instance, different blackening typologies are regarded to be closely linked to the composition and texture of the stone substrate and its probable age; this assumption has, however, been questioned (39).

Particular attention should be paid to the importance of pore structure and stone texture during the weathering process (40), as well as to the causes and effects of volume changes in connection with building material deterioration (41).

Stone research is often hampered by a want of non-destructive analytical methods with which stone interiors can be visualized.

Some non-destructive tests analyze the behaviour of certain physical properties (ultrasound transmission velocity, electrical conductivity, radar electromagnetic impulses) inside and/or on the surface of the materials. In stone, such behaviour can be correlated to petrophysical characteristics (mineral composition, anisotropy, porosity, fissures, dislocations) and degree of decay. Be it said in this regard that thermal and mechanical testing may damage such materials.

The aspects to be borne in mind when deploying these techniques are: (i) kind of signal (natural or artificial); (ii) contact, or otherwise, between sensors and stone; (iii) working procedures (reflection, echo-impulse, transmission on the surface or through the stone body); (iv) single or multiple signals from all possible positions (tomography). The main difficulty encountered is the correct 
interpretar correctamente los datos relativos a los materiales multifase y heterogéneos con anisotropía interna y distintos grados de discontinuidad.

La humedad es uno de los problemas más frecuentes en el mantenimiento y reparación de edificios históricos, por lo que determinar la ubicación y la diseminación de la humedad es un objetivo importante en todo proyecto de restauración. La termografía, entre otras, es una metodología versátil y no destructiva con un gran potencial en este sentido, aunque no es muy recomendable su uso para realizar mediciones in situ debido, por ejemplo, a los factores de forma, la atenuación atmosférica o la radiación externa. Otros problemas están relacionados con las características de las cámaras térmicas disponibles. Palomo y otros (42) desarrollaron una técnica basada en el uso de fuentes de radiación externas para aumentar las bandas de emisión del agua, mejorando de ese modo la detección de la humedad.

Es necesario que se desarrollen criterios adecuados para la limpieza, la conservación, la restauración y el refuerzo del patrimonio construido, así como que se empleen técnicas diagnósticas especiales para identificar las condiciones estructurales, especialmente cuando se sospecha la existencia de peligro. Asimismo es necesario contar con el conocimiento suficiente antes de emprender cualquier intervención, ya que de otro modo las medidas tomadas pueden ser ineficaces o perjudiciales para la "identidad" arquitectónica y artística de la obra.

La elección de un procedimiento de limpieza, por ejemplo, debería considerar no sólo los efectos mecánicos y químicos provocados por el propio tratamiento (Figura 14), sino también la naturaleza de los productos de degradación, cuya composición y textura y cuya interacción con el sustrato pétreo (figura 15) son a menudo heterogéneas (43).

En trabajos anteriores $(8,13,14,33,44$ y 45$)$ se proporcionan ejemplos de protocolos de investigación detallados.

\section{AGRADECIMIENTOS}

Este artículo está dedicado al difunto profesor Ugo Zezza, pionero en la investigación de las propiedades de la piedra e investigador principal de nuestro departamento.

Quedamos agradecidos a: Elisabetta Previde-Massara (ENI-Technologie de Milán); Cristina Sabbioni, Nadia Ghedini y Alessandra Bonazza (Instituto ISAC-CNR de Bolonia); y Carlos Rodríguez-Navarro (Departamento de Mineralogía y Petrología, Facultad de Ciencias e Instituto Andaluz del Patrimonio Histórico de Granada) por permitirnos utilizar sus datos. interpretation of the data referring to multi-phase and heterogeneous materials with internal anisotropy and different ranges of discontinuity.

Humidity is one of the most frequent problems encountered in the maintenance and repair of historic buildings: determining the location and dissemination of moisture is an important objective in any restoration project. Thermography among others is a versatile non-destructive tool with enormous potential in this respect; its use may not be overly convenient when taking "in situ" measurements, however, due for instance to shape factors, atmospheric attenuation or external radiation. Other problems are related to the characteristics of the thermocamera device available. Palomo et al. (42) developed a technique based on the use of external radiation sources to enhance the water emission bands, thereby improving the detection of moisture conditions.

The cleaning, preservation, restoration and strengthening of the built heritage necessitate the development of appropriate criteria, as well as the use of special diagnostic techniques for identifying structural conditions, especially in case of presumed risk. Furthermore, sufficient knowledge is needed before any manner of intervention is undertaken, for otherwise the measures taken may be useless or detrimental to the architectural and artistic "identity" of the structure.

The choice of a cleaning procedure, for instance, in addition to the mechanical and chemical effects due of the treatment itself (Figure 14), should take account of the nature of the decay by-products, whose composition and texture, as well as their interaction with the stone substrate (Figure 15), are often heterogeneous (43).

Examples of detailed research protocols are given in previous papers $(8,13,14,33,44$ and 45$)$.

\section{ACKNOWLEDGEMENTS}

This paper is dedicated to the late Professor Ugo Zezza, stone property research pioneer and head researcher in our department.

We are indebted to: Elisabetta Previde-Massara (ENITechnologie, Milano); Cristina Sabbioni, Nadia Ghedini and Alessandra Bonazza (Istituto ISAC-CNR, Bologna); and Carlos Rodriguez-Navarro (Departmento de Mineralogia-Petrologia, Facultad de Ciencias y Instituto Andaluz del Patrimonio Historico, Granada) for allowing us to use their data. 


\section{BIBLIOGRAFÍA / BIBLIOGRAPHY}

(1) Alcalde Moreno, M., Villegas Sánchez, R., Francisco Vales, J., Martín Pérez, A.: Diagnosis y tratamiento de la piedra. Inst. Ciencias Construcción "E. Torroja" - CSIC, Madrid, Monografía no 400, (1990).

(2) Veniale, F.: "Modern techniques of analysis applied to ancient ceramics". En:Veniale F., Zezza U. (ed.): Analytical methodologies for the investigation of damaged stones, European Communities-Cultural Heritage, Pavía, (1990).

(3) Zezza. U.: Le rocce dei monumenti - Composizione, proprietà, origini e impiego. En: "La pietra dei monumenti nel suo ambiente fisico", Scuola Europea Scienze e Materiali del Patrimonio Culturale, Centro Beni Culturali, Ravello, Ist. Poligrafico dello Stato, (1995), p. 33-64.

(4) Sebastián Pardo, E. (ed.): Técnicas de diagnóstico aplicadas a la conservación de los materiales de construcción en los edificios históricos. Instituto Andaluz del Patrimonio Histórico, Granada; Cuaderno Técnico, (1996).

(5) Esbert, R. M., Ordaz, J., Alonso F. J., Montoto, M. : Manual de diagnosis y tratamiento de materiales pétreos y cerámicos. Col·legi d'Aparelladors i Arquitectes Tècnics de Barcelona, (1997).

(6) Veniale, F.: Modern techniques for the study of stone decay in historical buildings. Schrift. angew. Geowiss., (1997), no 1, p. $173-179$.

(7) Monaco, L. M., Santamaria, A. : Indagini, prove e monitoraggio nel restauro degli edifici storici. Restauro, Quaderno 7, (1998).

(8) Calvi, G. P., Morandotti, M., Greco, A., Besana, D. : Diagnostica per il progetto di conservazione-Metodi, tecniche ed esempi. Centro Inter-dipartimentale Studi Ricerche Conservazione Beni Culturali, Universidad de Pavía, Quaderno 2, (2005).

(9) Maggetti, M., Messiga, B.: Geomaterials in cultural heritage. Special Publication, no 257, Geological Society Publishing House; (2006).

(10) Fitzner, B., Heinrichs, K.: "Damage diagnosis on stone monuments - Weathering forms, damage categories and damage indices". En: R. Pfikryl, Viles, H. A. (ed.): Understanding and managing stone decay, Karolinum Press, Praga, (2002), p. 11-56.

(11) NORMAL: Alterazioni macroscopiche dei materiali lapidei - Lessico. CNR-Istituto Centrale per il Restauro, Roma, (1988).

(12) Capponi, G., Lanari, P., Lodola, S., Magnatti, G., Parrini, U., Vecchi, A., Vedovello, S., Veniale, F.: "Il software 'Akira-Gis-Server': applicazione nelle mappature dei materiali costitutivi e dello stato di degrado della Torre di Pisa". Bolletino del Centro Ricerche Informatiche Beni Culturali, Scuola Normale Superiore, Pisa, vol. X, (2000), p. 115-126.

(13) Capponi, G., Vedovello, S. (ed.): Il restauro della Torre di Pisa. Opera Primaziale Pisana \& Istituto Centrale Restauro, Roma (también en inglés), (2000), 159 páginas.

(14) Settis, S. (ed.): "La Torre restituita. Gli studi e gli interventi che hanno consentito la stabilizzazione della Torre di Pisa". Bollettino d'Arte-Ministero Beni Culturali, pubblicazione speciale (3 volumi e tavole grafiche), Roma, (2005).

(15) Lodola, S.,, Veniale, F.: Studio e mappatura delle caratteristiche tessiturali dei marmi originali e di sostituzione delle colonne dei loggiati. Informe interno, Comité para la Protección de la Torre de Pisa, (2000).

(16) Macchi, G.: Mappatura combinata (tensioni massime e valutazioni non-distruttive) della qualità della muratura della Torre di Pisa. Informe interno, Comité para la Protección de la Torre de Pisa, (1995).

(17) Vedovello S., Rockwell, P.: Studio delle tecniche di lavorazione utilizzate per la finitura degli elementi della Torre di Pisa. Informe interno, Comité para la Protección de la Torre de Pisa; véase también (13) en este artículo, (2000), p. 60-72.

(18) Zezza F.: "Computerized analysis of stone decay in monuments". Actas del I simposio Conservation of Monuments in the Mediterranean Basin, Bari, (1989), p. 163-184.

(19) Bezoari, G., Veniale, F., Zezza, U.: "La micro-fotogrammetria come metodo di controllo non-distruttivo dello stato di degrado dei monumenti. Il degrado progressivo di un 'basso rilievo' della basilica di San Michele in Pavia dal 1940 al 1989". Giornale Prove Non-distruttive, no 3, (1989).

(20) Spalla, A., Galetto, R., Casella, V.: "Evaluation of the decay of bas-relieves of St. Michael basilica in Pavia". Actas del Congreso QuarryLaboratory-Monument, Pavía, vol. 1, (2000), p. 523-528.

(21) Veniale, F, Zezza, U.: "Nuove indagini sull'arenaria della basilica di San Michele in Pavia". Atti Ticinesi di Scienze della Terra, no 31, (1988), p. 253-268.

(22) Carò, F.: Characterization of mortars and plasters through image analyses see literature review therein. Tesis doctoral, Universidad de Pavía, (2004).

(23) Casadio, F., Chiari, G., Simon, S.: "Evaluation of binder/aggregate ratios in archaeological lime mortars with carbonate aggregate: a comparative assessment of chemical, mechanical and microscopic approaches". Archaeometry, no 47, (2005), p. (671-689).

(24) Franzini, M., Leoni, L., Lezzerini, M., Sartori, F.: "The mortar of the leaning Tower of Pisa - The product of a medieval technique for preparing high-strength mortars". European Journal of Mineralogy, no 12, (2000), p. 1151-1163.

(25) Veniale, F., Setti, M.: "I materiali usati per la costruzione della Torre Civica di Pavia - Loro condizioni e ruolo nelle cause del crollo". Bollettino della Società Pavese di Storia Patria, XCIX/Nuova Serie, LI, (1999), p. 479-488.

(26) Vendrell Saz, M., García Vallès, M., Molera, J., Veniale, F.: "Crusts, patinas and surface deposits on building stones of the leaning Tower of Pisa". Actas del IV Simposio Internacional Conservation of Monuments in the Mediterranean Basin, Rodas, 1, (1997), p. 173-182.

(27) Rodríguez Navarro, C., Sebastián Pardo, E., Doehne, E., Ginell, W. S.: "The role of sepiolite-palygorskite in the decay of ancient Egyptian limestone sculptures". Clay \& Clay Minerals, no 46, (1998), p. 414-422.

(28) Jacobs, P., Sevens, E., Kunnen, M.: "Principles of computerized X-ray tomography and applications to building materials". Science of the Total Environment, no 167, (1985), p. 161-170.

(29) Veniale, F., Setti, M., Rodríguez Navarro, C., Lodola, S.: "Role of clay constituents in stone decay processes". Mater. Construcc., Especial 50 Aniversario, vol. 51, no 263-264, (2002), p. 163-182.

(30) Bonazza, A., Sabbioni, C., Ghedini, N.: "Quantitative data on carbon fractions in interpretation of black crusts and soiling on European built heritage". Atmospheric Environment, 39, (2005), p. 2607-2618. 
(31) Ghedini, N., Sabbioni, C., Bonazza, A., Gobbi, G. C.: "Chemical-thermal methodology for carbon speciation in damage layers on building surfaces". Environmental Science \& Technology, 40, (2006), p. 939-944.

(32) Birginie, J. M., Rivas, T., Prieto, B., Auger, F.: "Comparación de la resistencia a la alteración por niebla salina de dos calizas utilizadas en la construcción mediante metodos ponderales, metodos acusticos y tratamiento de imágenes". Mater. Construcc., vol. 50, n 259, (2000), p. 27-43.

(33) Previde-Massara, E., Millini, R., Buroni, M., Perego, G.: "The superficial state of the stone of St. Peter (Vatican) in Rome". Actas del Congreso Internacional Quarry-Laboratory-Monument, Pavía, 1, (2000), 469-474.

(34) Setti, M., Veniale, F.: "Degradation conditions of the materials constituting the lower loggia of the façade of Pavia cathedral". En: Calvi, G. P. (ed.): Il Duomo di Pavia tra conoscenza, conservazione e valorizzazione, (2007), p. 135-141.

(35) Zezza, U.: "Quarry-laboratory-monument as fundamental domains for stone conservation studies of the architectural heritage". Actas del II Congreso sobre Rehabilitación del Patrimonio Arquitectónico y Edificación, Mar del Plata (Argentina), (1995), p. 227-231.

(36) Zezza, U. (1992): "Decay evolution depending on the textural anisotropy of marbles in monuments". Actas del II Congreso Conservation of Monuments in the Mediterranean Basin, Ginebra, (1992), p. 1, 273-286.

(37) Zezza, F.: "Marine aerosol and stone decay". Science of the Total Environment, (1995), no 167, p. 123-143.

(38) Zezza, F. (ed.): "Origin, mechanisms and effects of salts on the degradation of monuments in marine and continental environments". Actas del Seminario de la Comisión Europea Protection and Conservation of the European Cultural Heritage, Informe n 4, (1996).

(39) Vendrell Saz, M., Krumbein, W. E., Urzi, C., García Vallès, M.: "Are patinas of the Mediterranean monuments really related to the rock substrate?". Actas del VIII Congreso Deterioration and Conservation of Stone, Berlín, (1996), no 2, p. 609-624.

(40) Jeannette, D.: "Importance of the pore structure during the weathering processes of stones in monuments". En: H. Paquet, N. Clauer (ed.): Soil and sediments, Springer, (1997), capítulo 9, p. 177-190.

(41) Kühnel, R. A.: "Cause and consequence: volume changes behind material deterioration". Materials Characterization, (2004), n 53, p. $171-180$.

(42) Palomo, A., Gayo, E., Massa, M. (2000): "La radiación externa controlada como técnica de potenciación de las señales registradas con la termografía infrarroja". Mater. Construcc., (2000), vol. 50, n० 259, p. 45-55.

(43) Franzini, M., Leoni, L., Sartori, F., Veniale, F.: "The leaning Tower of Pisa: occurrence and distribution of the masonry decay by-products". Science and Technology for Cultural Heritage, (1997), nº 6, p. 135-144.

(44) Alessandrini, G., Bugini, R. (ed.): La Certosa di Pavia - Passato e presente nella facciata della chiesa. Centro Studi "G. Bozza" Studio Cause Deperimento e Metodi Conservazione Opere d'Arte/CNR, Monografia: serie Ingegneria e Architettura, (1998), 319 páginas.

(45) Setti, M., Nicola, C., López-Galindo, A. Lodola, S., Maccabruni, C., Veniale, F.: "Archaeometric investigation of bricks from the ancient defense walls of Pavia town (nothern Italy)" Mater. Construcc. 56, 283, (2006), p. 5-23. 